\title{
Opuntia dillenii (Ker Gawl.) Haw., Seeds Oil Antidiabetic Potential Using In Vivo, In Vitro, In Situ, and Ex Vivo Approaches to Reveal Its Underlying Mechanism of Action
}

\author{
Mohamed Bouhrim ${ }^{1}$, Hayat Ouassou ${ }^{1}$, Salima Boutahiri ${ }^{2}$, Nour Elhouda Daoudi ${ }^{1}$, Hamza Mechchate ${ }^{3, *(\mathbb{D} \text {, }}$ \\ Bernard Gressier ${ }^{4}$, Bruno Eto ${ }^{4,5}$, Hamada Imtara ${ }^{6}$, Amal A. Alotaibi ${ }^{7}$, Mohammed Al-zharani ${ }^{8}$, \\ Abderrahim Ziyyat ${ }^{1}$, Hassane Mekhfi ${ }^{1}$, Abdelkhaleq Legssyer ${ }^{1}$, Mohammed Aziz ${ }^{1}$ and Mohamed Bnouham ${ }^{1, *}$
}

check for updates

Citation: Bouhrim, M.; Ouassou, H.; Boutahiri, S.; Daoudi, N.E.

Mechchate, H.; Gressier, B.; Eto, B.; Imtara, H.; A. Alotaibi, A.; Al-zharani, M.; et al. Opuntia dillenii (Ker Gawl.) Haw., Seeds Oil Antidiabetic Potential Using In Vivo, In Vitro, In Situ, and Ex Vivo Approaches to Reveal Its Underlying Mechanism of Action. Molecules 2021, 26, 1677. https://doi.org/10.3390/molecules 26061677

Academic Editor: Julian Weghuber

Received: 2 February 2021

Accepted: 11 March 2021

Published: 17 March 2021

Publisher's Note: MDPI stays neutral with regard to jurisdictional claims in published maps and institutional affiliations.

Copyright: (C) 2021 by the authors Licensee MDPI, Basel, Switzerland. This article is an open access article distributed under the terms and conditions of the Creative Commons Attribution (CC BY) license (https:/ / creativecommons.org/licenses/by/ $4.0 /)$.
1 Laboratory of Bioresources, Biotechnology, Ethnopharmacology, and Health, Faculty of Sciences, Mohammed First University, Oujda B.P. 717, Morocco; mohamed.bouhrim@gmail.com (M.B.); hayatouassou@gmail.com (H.O.); Nourelhoudada95@gmail.com (N.E.D.); ziyyat@yahoo.fr (A.Z.); hmekhfi@yahoo.fr (H.M.); alegssyer@yahoo.fr (A.L.); azizmo5@yahoo.fr (M.A.)

2 Research Team on the Chemistry of Bioactive Molecules and Environment, Faculty of Sciences, Moulay Ismaïl University, Meknes, B.P. 11201 Zitoune Meknes, Morocco; boutahirisalima@gmail.com

3 Laboratory of Biotechnology, Environment, Agrifood, and Health, University of Sidi Mohamed Ben Abdellah, Faculty of Sciences Dhar el Mahraz, Fez B.P. 1796, Morocco

4 Laboratory of Pharmacology, Pharmacokinetics, and Clinical Pharmacy, Faculty of Pharmaceutical and Biological Sciences, B.P. 83 Lille, France; bernard.gressier@univ-lille2.fr (B.G.);

Etobrunoalves1@hotmail.fr (B.E.)

5 Laboratories-TBC, Faculty of Pharmaceutical and Biological Sciences, B.P. 83 Lille, France

6 Faculty of Arts and Sciences, Arab American University Palestine, Jenin 240, Palestine; hamada.tarayrah@gmail.com

7 Basic Science Department, College of Medicine, Princess Nourah bint Abdulrahman University, Riyadh 11671, Saudi Arabia; amaalotaibi@pnu.edu.sa

8 Biology Department, College of Science, Imam Mohammad ibn Saud Islamic University (IMSIU), Riyadh 11623, Saudi Arabia; mmyalzahrani@imamu.edu.sa

* Correspondence: Hamza.mechchate@usmba.ac.ma (H.M.); mbnouham@yahoo.fr (M.B.)

Abstract: Opuntia dillenii Ker Gawl. is one of the medicinal plants used for the prevention and treatment of diabetes mellitus (DM) in Morocco. This study aims to investigate the antihyperglycemic effect of Opuntia dillenii seed oil (ODSO), its mechanism of action, and any hypoglycemic risk and toxic effects. The antihyperglycemic effect was assessed using the OGTT test in normal and streptozotocin (STZ)-diabetic rats. The mechanisms of action were explored by studying the effect of ODSO on the intestinal absorption of D-glucose using the intestinal in situ single-pass perfusion technique. An Ussing chamber was used to explore the effects of ODSO on intestinal sodium-glucose cotransporter 1 (SGLT1). Additionally, ODSO's effect on carbohydrate degrading enzymes, pancreatic $\alpha$-amylase, and intestinal $\alpha$-glucosidase was evaluated in vitro and in vivo using STZ-diabetic rats. The acute toxicity test on mice was performed, along with a single-dose hypoglycemic effect test. The results showed that ODSO significantly attenuated the postprandial hyperglycemia in normal and STZ-diabetic rats. Indeed, ODSO significantly decreased the intestinal D-glucose absorption in situ. The ex vivo test (Ussing chamber) showed that the ODSO significantly blocks the SGLT1 $\left(\mathrm{IC}_{50}=60.24 \mu \mathrm{g} / \mathrm{mL}\right)$. Moreover, ODSO indu $\backslash$ ced a significant inhibition of intestinal $\alpha$-glucosidase $\left(\mathrm{IC}_{50}=278 \pm 0.01 \mu \mathrm{g} / \mathrm{mL}\right)$ and pancreatic $\alpha$-amylase $\left(\mathrm{IC}_{50}=0.81 \pm 0.09 \mathrm{mg} / \mathrm{mL}\right)$ in vitro. A significant decrease of postprandial hyperglycemia was observed in sucrose/starch-loaded normal and STZ-diabetic ODSO-treated rats. On the other hand, ODSO had no risk of hypoglycemia on the basal glucose levels in normal rats. Therefore, no toxic effect was observed in ODSO-treated mice up to $7 \mathrm{~mL} / \mathrm{kg}$. The results of this study suggest that ODSO could be suitable as an antidiabetic functional food.

Keywords: Opuntia dillenii; seeds oil; diabetes mellitus; antihyperglycemic; streptozotocin; intestinal glucose absorption; Ussing chamber; intestinal $\alpha$-glucosidase; pancreatic $\alpha$-amylase; biological activity; medicinal plant 


\section{Introduction}

Diabetes mellitus is chronic metabolic trouble marked by a high blood sugar level due to abnormal insulin synthesis or action [1,2]. Among the most well-known types of diabetes is type 1 diabetes, where the body does not produce insulin or in insufficient quantities, which develops due to lifestyle changes, viral infections, toxins ingestion, and genetic predisposition. Moreover, type 2 diabetes is due to insulin resistance leading to long-term insulin deficiency. It is strongly related to obesity or overweight, increasing age, ethnicity, and family history [3]. Currently, the global prevalence of diabetes is $9.3 \%$; this number will reach $10.2 \%$ by 2030 and $10.9 \%$ by 2045 [4]. Globally, about $50 \%$ of diabetes cases are undiagnosed owing to the unawareness of symptoms, and the majority of these cases come from low- and middle-income countries [5]. Furthermore, poor blood D-glucose control in diabetic patients leads to permanent hyperglycemia [6]. In diabetic patients, postprandial hyperglycemia is involved in plasmatic and cellular proteins glycation, which take part in the development of diabetes complications [7-9]. In this regard, diabetes mellitus (DM) management requires accurate postprandial glycemic control through decreasing the glucose absorption [10]. This is possible via the inhibition of carbohydrate enzymes and/or inhibition of glucose absorption by the intestinal epithelial cells $[9,10]$. Different treatments are currently used to manage diabetes, such as insulin, dietetic therapies, and pharmacotherapy, which exert antidiabetic effects by different mechanisms. These mechanisms include increasing D-glucose's cellular intake by biguanides and thiazolidinediones, stimulating insulin secretion by sulfonylureas and meglitinides, delaying carbohydrates absorption from the luminal intestinal space by intestinal $\alpha$-glucosidase inhibitors, and reducing hepatic gluconeogenesis by biguanides [11-13]. Since antiquity, people have used plants not only to perfume themselves, clothe themselves, feed themselves, etc. but, also, to heal themselves [14]. Indeed, thanks to the availability, low cost, and therapeutic effectiveness of these natural products, the population rate that uses medicinal plants to treat disease spills is high and estimated as $80 \%$ according to a WHO report [15]. Many medicinal plants are used traditionally in the management of diabetes throughout the world $[16,17]$. Marles and Farnsworth estimated that more than 1000 plant species are being used against DM [18]. The efficacy and safety of some plants have been sufficiently validated by clinical use over thousands of years [19]. The Opuntia plant belongs to the family of Cactaceae [20]. It originated from Mexico and was first observed in North Africa during the sixteenth century [21]. Actually, up to 1500 species belong to the Opuntia genus, and they are distributed in several regions in the world, like the Mediterranean countries, Europe, and sub-Saharan Africa [22]. The majority of these species are characterized by the production of edible and aromatic fruits [23]. This Opuntia plant spreads wildly in arid and semi-arid regions, where there is a high use and low demand for water to increase the production of Cactus, as highlighted by the Food and Agriculture Organization [24]. Opuntia dillenii Ker Gawl. is a Cactus species, growing in Western and Northeastern Morocco. It plays an important role in subsistence agriculture. The Opuntia dillenii fruit is characterized by a sour taste and the presence of a large number of seeds. This plant is used in alternative medicine to treat many diseases, such as DM [25-27]. Opuntia dillenii is used in traditional medicine to treat diabetes [28]. In Tunisia, the ripe fruit of opuntia dillenii is used in traditional medicine as an antidiabetic [29]. In Pakistan, Opuntia dillenii is also used for the treatment of diabetes [30]. In traditional Canadian medicine, the fruit of Opuntia dillenii is used as an antidiabetic agent [31]. However, little interest has been given to the use of the fruit seeds by traditional medicine, because the body is unable to digest them and, therefore, to benefit from their constitutions. Several scientific studies have been interested in studying the different vegetative parts of Opuntia to assess or confirm their beneficial biological effects on various diseases. Over the last few years, researchers have been interested in studying the seed oil of Opuntia dillenii and have found that they are rich in very active molecules [26,32]. 
Opuntia dillenii seed oil contains a high amount of linoleic acid, $\beta$-sitosterol, and $\gamma$-tocopherols, the main components of constitutive fatty acids, phytosterols, and tocopherols, respectively [33]. These phytochemical compounds have shown very important antidiabetic properties in several studies $[34,35]$. Previous papers have reported the potential bioeffects of ODSO, including antioxidant, anti-inflammatory, and hepatoprotective activities [36,37]. Furthermore, in a previous work, the antidiabetic effect of ODSO was studied, but the mechanism of action still has not been elucidated [38,39]. The present work aims to study the postprandial glycemic control by ODSO through an oral glycemic load shedding light on the possible mechanisms during the absorptive process by targeting digestive enzymes ( $\alpha$-amylase and $\alpha$-glucosidase) and glucose movement across the intestinal epithelial barrier.

\section{Results}

\subsection{Yield of Extraction}

The maceration of Opuntia dillenii seeds for $24 \mathrm{~h}$ with the use of petroleum ether as a lipid extractor gave a yield of $7 \%$ (oil component from the dry weight).

\subsection{Acute Toxicity}

The results of this acute toxicity test showed that ODSO is not toxic at a dose up to $7 \mathrm{~mL} / \mathrm{kg}$. It did not cause any signs of toxicity (diarrhea, vomiting, abnormal mobility, etc.) or mortality during the entire surveillance period (14 days).

\subsection{Hypoglycemic Test in Non-Diabetic Rats}

The results of this test showed that the administration of ODSO at a dose of $2 \mathrm{~mL} / \mathrm{kg}$ did not produce a risk of hypoglycemia on the basal blood D-glucose level of nondiabetic rats. The change in blood sugar during the six $h$ after ODSO administration was not significant compared to the control group. In contrast, the glibenclamide caused a significant decrease $(p<0.001)$ during the two, four, and six $h$, compared to the control group. Moreover, the comparison of the effect of ODSO with that of glibenclamide showed that there has a significant $(p<0.001)$ difference between them at the $120 \mathrm{~min}, 240$, and 360 min (Figure 1A). Besides, the area under the curve (AUC D-glucose) for the ODSO group $(5932 \pm 169 \mathrm{mg} / \mathrm{dL} / \mathrm{h}$ ) was not significantly different, compared to the control group $(5625 \pm 169 \mathrm{mg} / \mathrm{dL} / \mathrm{h})$. The area under the curve for the glibenclamide group was significantly lower $(p<0.001)(4777 \pm 184 \mathrm{mg} / \mathrm{dL} / \mathrm{h})$ compared to the area under the curve of the control group $(5625 \pm 169 \mathrm{mg} / \mathrm{dL} / \mathrm{h})$. Moreover, there was a significant $(p<0.001)$ difference between the area under the curves of the ODSO and glib groups (Figure 1B).

\subsection{Antihyperglycemic Study in Nondiabetic and Diabetic Rats}

\subsubsection{Nondiabetic Rats}

Oral administration of ODSO at $0.8 \mathrm{~mL} / \mathrm{kg} 30 \mathrm{~min}$ prior to D-glucose overload in nondiabetic rats significantly reduced the postprandial hyperglycemia at $90 \mathrm{~min}(p<0.001$; $1 \pm 4 \mathrm{~g} / \mathrm{L}), 150 \mathrm{~min}(p<0.05 ; 108 \pm 15 \mathrm{mg} / \mathrm{dL})$, and $210 \mathrm{~min}(p<0.001 ; 103 \pm 4 \mathrm{mg} / \mathrm{dL})$ compared with the group of rats pretreated with distilled water in which a D-glucose overload-induced remarkable hyperglycemia was observed: at $90 \mathrm{~min}(153 \pm 8 \mathrm{mg} / \mathrm{dL}), 150$ $\min (153 \pm 9 \mathrm{mg} / \mathrm{dL})$, and $210 \mathrm{~min}(145 \pm 7 \mathrm{mg} / \mathrm{dL})$. Similarly, glibenclamide significantly inhibited postprandial hyperglycemia for three $\mathrm{h}$ following the D-glucose overload at 90 $\min (p<0.001 ; 95 \pm 4 \mathrm{mg} / \mathrm{dL}), 150 \mathrm{~min}(p<0.001 ; 83 \pm 3 \mathrm{mg} / \mathrm{dL})$, and $210 \mathrm{~min}(p<0.001 ;$ $78 \pm 6 \mathrm{mg} / \mathrm{dL}$ ) compared with the group of rats pretreated with distilled water. Moreover, the comparison of the effect of ODSO with that of glibenclamide showed that it did not have a significant difference between them at $90 \mathrm{~min}$ and $150 \mathrm{~min}$, but it was significant after $210 \min (p<0.05)$ (Figure 2A). The area under the curve (AUC D-glucose) was significantly $(p<0.01)$ lower in rats treated with ODSO $(6062 \pm 1003 \mathrm{mg} / \mathrm{dL} / \mathrm{h})$ than in rats treated with distilled water $(8098 \pm 806 \mathrm{mg} / \mathrm{dL} / \mathrm{h})$. Besides, the area under the glibenclamide curve was significantly $(p<0.001)$ lower $(5322 \pm 545 \mathrm{mg} / \mathrm{dL} / \mathrm{h})$ compared to the area under the 
curve of the distilled water-treated rats $(8098 \pm 806 \mathrm{mg} / \mathrm{dL} / \mathrm{h})$. Moreover, there was not a significant difference between the area under the curves of the ODSO and glib groups (Figure 2B).

(A)
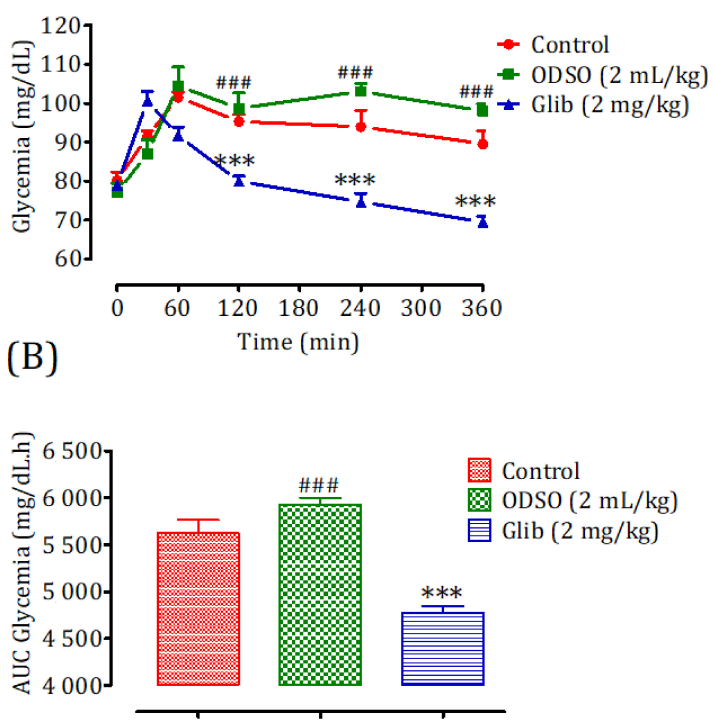

Figure 1. Changes in the basal blood D-glucose (A) and area under the basal blood D-glucose curves (B) in normal rats after administration of the tested products (ODSO and glibenclamide). ODSO: Opuntia dillenii seed oil. The values are the means \pm SEM $(n=6)$. ODSO: Opuntia dillenii seed oil. ${ }^{* * *} p<0.01$ in comparison with the control and ${ }^{\# \#} p<0.001$ compared to the glib group. Glib: glibenclamide and AUC: area under the curve.

(A)

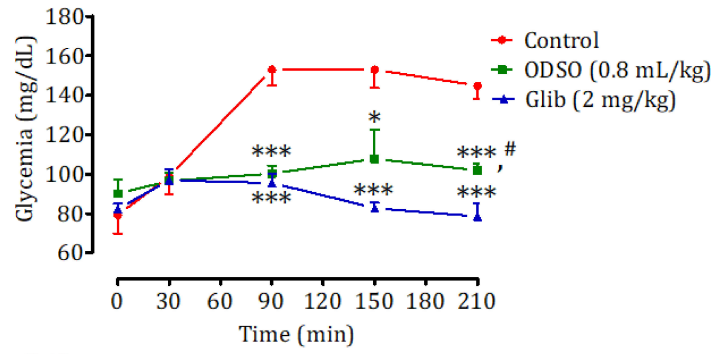

(B)

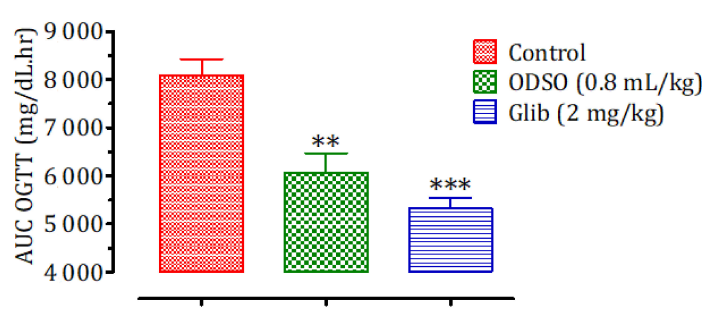

Figure 2. Effect of ODSO and glibenclamide on the change in postprandial glycemia in normal rats (A) and with a representation in the area under curves (B). ODSO: Opuntia dillenii seed oil. The values are the means $\pm \operatorname{SEM}(n=6) .{ }^{*} p<0.05,{ }^{* *} p<0.01$, and ${ }^{* * *} p<0.001$ compared to the control. ${ }^{*}$ $p<0.05$ compared to the glib group. 


\subsubsection{Diabetic Rats}

The oral administration of ODSO at $1 \mathrm{~mL} / \mathrm{kg} 30 \mathrm{~min}$ before the D-glucose overload in diabetic rats significantly reduced the postprandial hyperglycemia at $90 \mathrm{~min}(p<0.01$; $307 \pm 8 \mathrm{mg} / \mathrm{dL}), 150 \mathrm{~min}(p<0.05 ; 314 \pm 1 \mathrm{mg} / \mathrm{dL})$, and $210 \mathrm{~min}(p<0.001 ; 311 \pm 9 \mathrm{mg} / \mathrm{dL})$ compared with the group of rats pretreated with distilled water in which a D-glucose overload-induced remarkable hyperglycemia was observed: at $90 \mathrm{~min}(388 \pm 13 \mathrm{mg} / \mathrm{dL})$, $150 \mathrm{~min}(385 \pm 8 \mathrm{mg} / \mathrm{dL})$, and $210 \mathrm{~min}(398 \pm 7 \mathrm{mg} / \mathrm{dL})$. Similarly, glibenclamide significantly inhibited postprandial hyperglycemia during the three $\mathrm{h}$ following the D-glucose overload at $90 \mathrm{~min}(p<0.001 ; 280 \pm 18 \mathrm{mg} / \mathrm{dL}), 150 \mathrm{~min}(p<0.01 ; 255 \pm 26 \mathrm{mg} / \mathrm{dL})$, and $210 \mathrm{~min}(p<0.001 ; 251 \pm 25 \mathrm{mg} / \mathrm{dL})$ compared with the group of rats pretreated with distilled water. Moreover, the comparison of the effect of ODSO with that of glibenclamide showed that there was not a significant difference between them at $90 \mathrm{~min}, 150 \mathrm{~min}$, and $210 \mathrm{~min}$ (Figure 3A). The area under the curve (AUC D-glucose) was significantly $(p<0.05)$ lower in rats pretreated with ODSO $(17,576 \pm 987 \mathrm{mg} / \mathrm{dL} / \mathrm{h})$ than in rats pretreated with distilled water $(21,181 \pm 1204 \mathrm{mg} / \mathrm{dL} / \mathrm{h})$. Additionally, the glibenclamide area under the curve was significantly $(p<0.01)$ lower $(15,545 \pm 3079 \mathrm{mg} / \mathrm{dL} / \mathrm{h})$ compared to the area under the curve of rats pretreated with distilled water $(21,181 \pm 1204 \mathrm{mg} / \mathrm{dL} / \mathrm{h})$. Moreover, there was not a significant difference between the area under the curves of the ODSO and glib groups (Figure 3A).

\section{(A)}

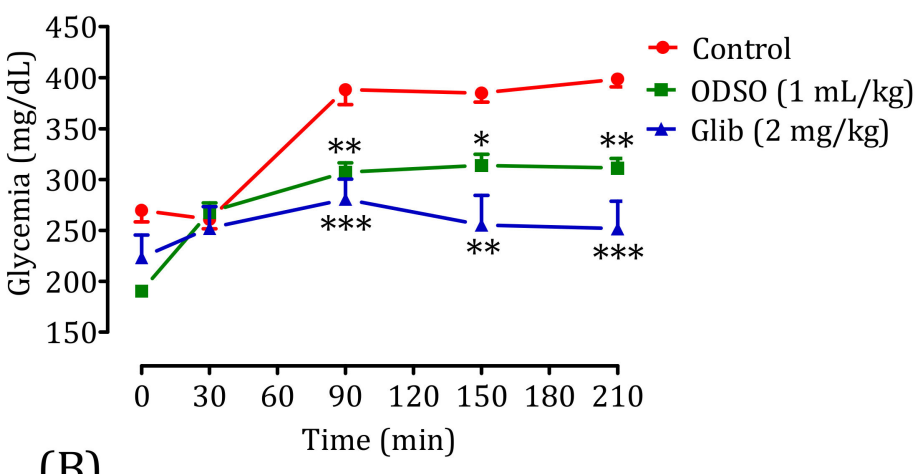

(B)

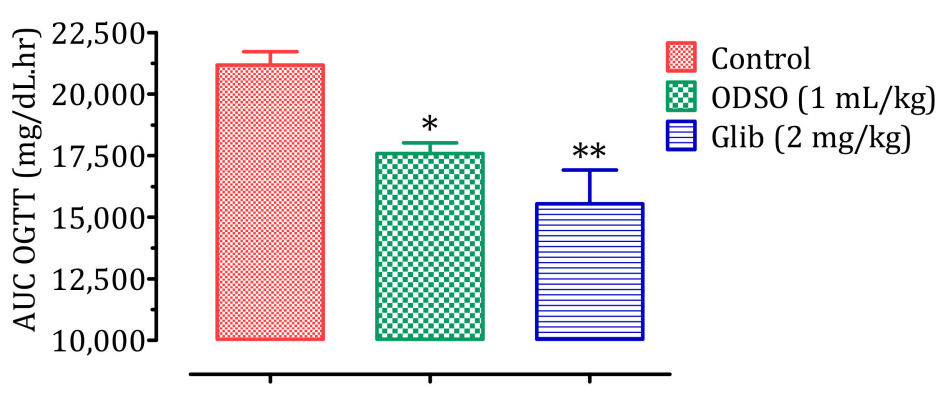

Figure 3. Effect of the oil (ODSO) and glibenclamide (Glib) on the postprandial glycemia variations in diabetic rats (A), with a representation of the area under curves (B). ODSO: Opuntia dillenii seed oil. The values are the means $\pm \operatorname{SEM}(n=6) .{ }^{*} p<0.05,{ }^{* *} p<0.01$, and ${ }^{* * *} p<0.001$ compared to the control.

\subsection{Intestinal Absorption Inhibition of D-Glucose, In Situ}

The results of this test showed that ODSO at a dose of $1 \mathrm{~mL} / \mathrm{kg}$ had a significant inhibitory effect of the intestinal absorption of D-glucose in normal Wistar rats $(p<0.001$; $6.07 \pm 0.55 \mathrm{mg} / 10 \mathrm{~cm} / \mathrm{h})$ in situ compared with the control group $(9.02 \pm 0.36 \mathrm{mg} / 10 \mathrm{~cm} / \mathrm{h})$. Besides, the antidiabetic drug phlorizin also had a significant inhibitory effect on the in- 
testinal absorption of D-glucose $(p<0.001 ; 4.01 \pm 0.41 \mathrm{mg} / 10 \mathrm{~cm} / \mathrm{h})$. Moreover, the effect of ODSO was significantly $(p<0.001)$ lower than that of phlorizin (Figure 4$)$.

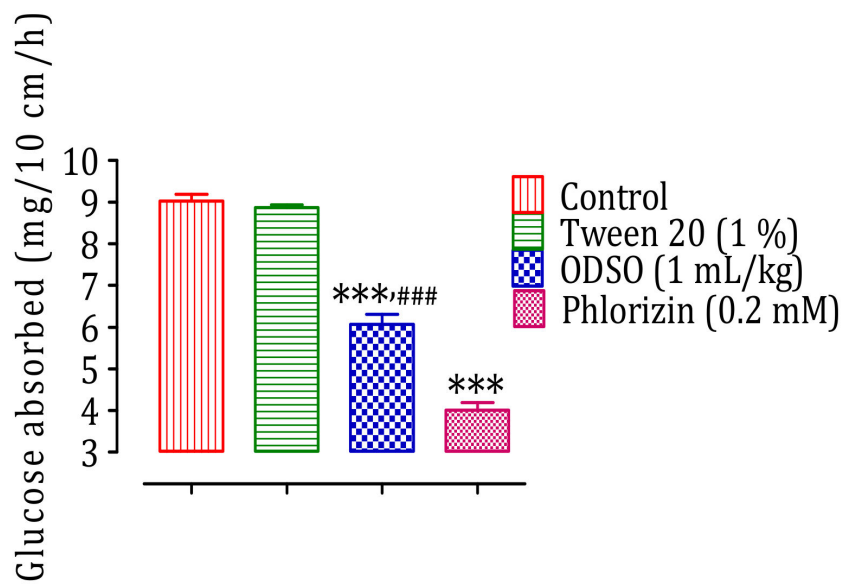

Figure 4. Inhibitory effect of the intestinal absorption of D-glucose by oil (ODSO) and phlorizin in situ. ODSO: Opuntia dillenii seed oil. The values are the means $\pm \operatorname{SEM}(n=6)$. ${ }^{* * *} p<0.001$ compared to the control and ${ }^{\# \#} p<0.001$ compared to the Phlorizin group.

\subsection{The ODSO Inhibits the Sodium-Dependent Absorption of D-Glucose}

We used a short-circuit technique in an Ussing chamber to characterize the effect of ODSO on intestinal glucose transport. The effect of ODSO on the electrogenic intestinal absorption of D-glucose is shown in Figure 5. After reaching a steady state (at least $40 \mathrm{~min}$ ), mouse jejunal mucosa was challenged on the mucosal side with 30-mM D-glucose (Figure 5A). The results showed that the introduction of ODSO five min before the addition of D-glucose attenuated the increase in the short-circuit current induced by D-glucose (Figure 5B). The area under the curve of the D-glucose absorption after the introduction of ODSO $\left(37.97 \pm 14.40 \mu \mathrm{A} / \mathrm{cm}^{2}\right)$ was significantly $(p<0.01)$ lower than the area under the curve of the D-glucose absorption without the addition of ODSO $\left(98.93 \pm 31.30 \mu \mathrm{A} / \mathrm{cm}^{2}\right)$ (Figure 5C). The introduction of ODSO into the mucosal reservoir five min before the addition of D-glucose induced a significant dependent concentration inhibition of the short-circuit current (Isc) $\left(\mathrm{IC}_{50}=60.24 \mu \mathrm{g} / \mathrm{mL}\right.$ ), as shown in Figure 5D.
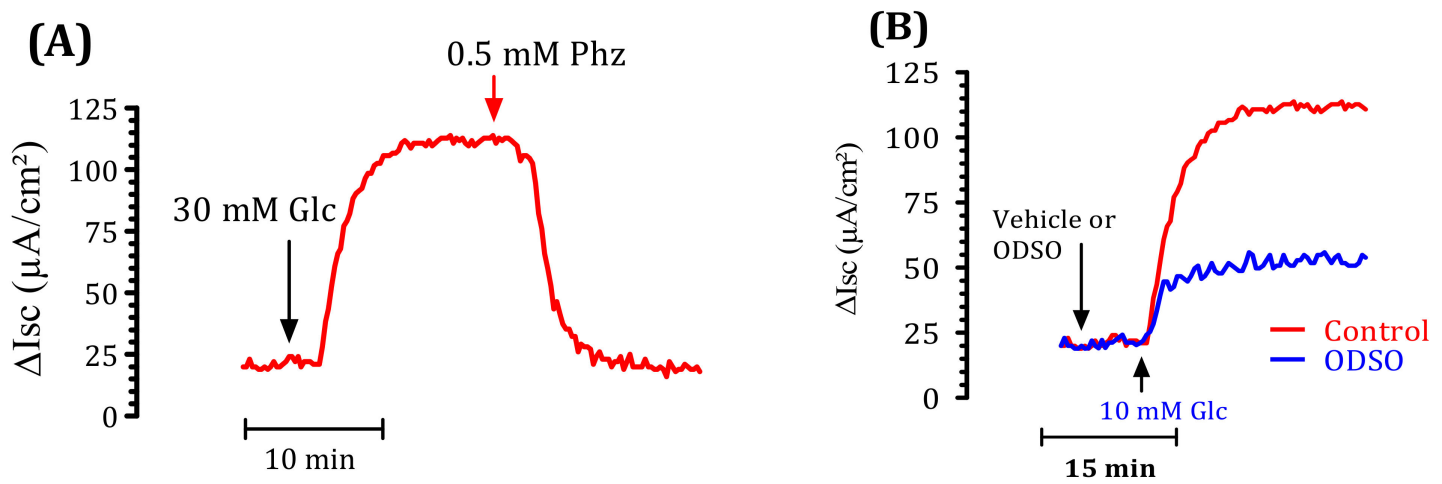

Figure 5. Cont. 

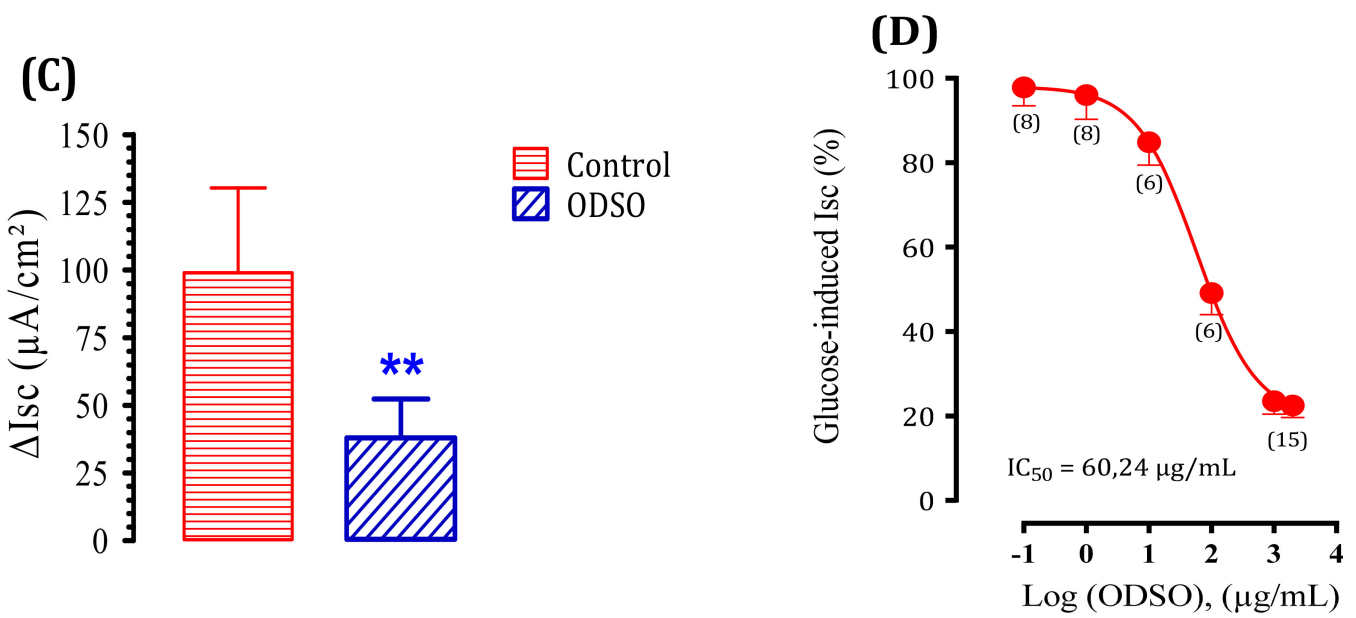

Figure 5. Effect of ODSO on the glucose-induced short-circuit current (Isc). (A) Typical recording of the inhibition of Isc $\left(\mu \mathrm{A} / \mathrm{cm}^{2}\right)$ across the mouse jejunum segment isolated in the Ussing chamber by phlorizin (PHZ) added on the mucosal side 10 min before the luminal D-glucose challenge $(30 \mathrm{mM})$. This figure showed that PHZ induced the total inhibition of Isc. (B) ODSO $(1 \mathrm{mg} / \mathrm{mL})$ diluted in a Ringer solution was added on the mucosal side $10 \mathrm{~min}$ before the luminal D-glucose challenge $(30 \mathrm{mM})$. An increase in Isc reflects glucose-related electrogenic sodium absorption through (Na+)-glucose cotransporter-1, SGLT1. The maximal increase in Isc was measured at the plateau. (C) The AUC of the vehicle and ODSO effects on D-glucose induced Isc. (D) The concentration-response inhibition of glucose-induced Isc is expressed as a \% of the maximum effect induced by $0.5 \mathrm{mM}$ of phlorizin (PHZ); $n=6-15^{* *} p<0.001$ tissues studied.

\subsection{Inhibition Assay of Pancreatic $\alpha$-Amylase Activity In Vitro}

The result of the effect of ODSO on the activity of pancreatic $\alpha$-amylase in vitro is shown in Figure 6. Indeed, the activity of the pancreatic $\alpha$-amylase enzyme was significantly $(p<0.001)$ inhibited in the presence of ODSO. The inhibitory effect of the pancreatic $\alpha$-amylase enzyme is proportional to the ODSO concentration, with an $\mathrm{IC}_{50}=0.81 \pm 0.09 \mathrm{mg} / \mathrm{mL}$ compared with the control test. Besides, this inhibitory effect of $\alpha$-amylase by ODSO is significantly $(p<0.001)$ lower than that of acarbose, with an $\mathrm{IC}_{50}=0.33 \pm 0.01 \mathrm{mg} / \mathrm{mL}$.

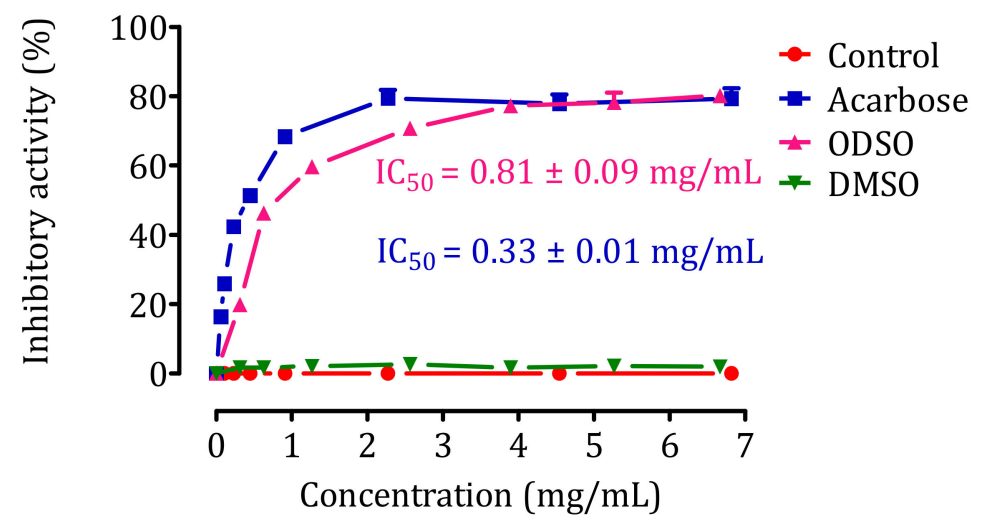

Figure 6. Inhibitory effect of pancreatic $\alpha$-amylase activity by ODSO and acarbose in vitro. The values are the means $\pm \operatorname{SEM}(n=3)$. ODSO: Opuntia dillenii seed oil.

\subsection{Inhibition Assay of Pancreatic $\alpha$-Amylase Activity in Non-Diabetic and Diabetic Rats 2.8.1. Nondiabetic Rats}

The oral administration of ODSO at $0.8 \mathrm{~mL} / \mathrm{kg} 30 \mathrm{~min}$ before a starch overload in nondiabetic rats significantly reduced the postprandial hyperglycemia at $30 \mathrm{~min}$ $(p<0.01 ; 132 \pm 7 \mathrm{mg} / \mathrm{dL})$ and $60 \mathrm{~min}(p<0.05 ; 99 \pm 23 \mathrm{mg} / \mathrm{dL})$, and no effect was observed at $120 \mathrm{~min}$ in comparison with the group of rats pretreated with distilled water in which a starch overload-induced remarkable hyperglycemia was observed: at 
$30 \mathrm{~min}(148 \pm 06 \mathrm{mg} / \mathrm{dL})$ and $60 \mathrm{~min}(118 \pm 17 \mathrm{mg} / \mathrm{dL})$. Similarly, the acarbose intake significantly inhibited postprandial hyperglycemia during the two hours following the starch overload at $30 \mathrm{~min}(p<0.01 ; 97 \pm 6 \mathrm{mg} / \mathrm{dL})$ and $60 \mathrm{~min}(p<0.01 ; 97 \pm 6 \mathrm{mg} / \mathrm{dL})$ compared to the group of rats pretreated with distilled water. At $120 \mathrm{~min}$, the blood sugar in all groups was similar. Moreover, the comparison of the effect of ODSO with that of acarbose showed that there was a significant difference between them at $30 \mathrm{~min}$ and no significant difference at $60 \mathrm{~min}$ and $120 \mathrm{~min}$ (Figure 7A). The area under the curve (AUC Dglucose) was significantly $(p<0.05)$ lower in rats treated with ODSO $(6222 \pm 467 \mathrm{mg} / \mathrm{dL} / \mathrm{h})$ than in rats treated with distilled water $(6822 \pm 437 \mathrm{mg} / \mathrm{dL} / \mathrm{h})$. Besides, the area under the curve of acarbose was significantly $(p<0.001)$ lower $(5754 \pm 293 \mathrm{mg} / \mathrm{dL} / \mathrm{h})$ compared to the area under the curve of the water-treated rats $(6822 \pm 437 \mathrm{mg} / \mathrm{dL} / \mathrm{h})$. Moreover, there was not a significant difference between the area under the curves of the ODSO and acarbose groups (Figure 7B).

\section{(A)}

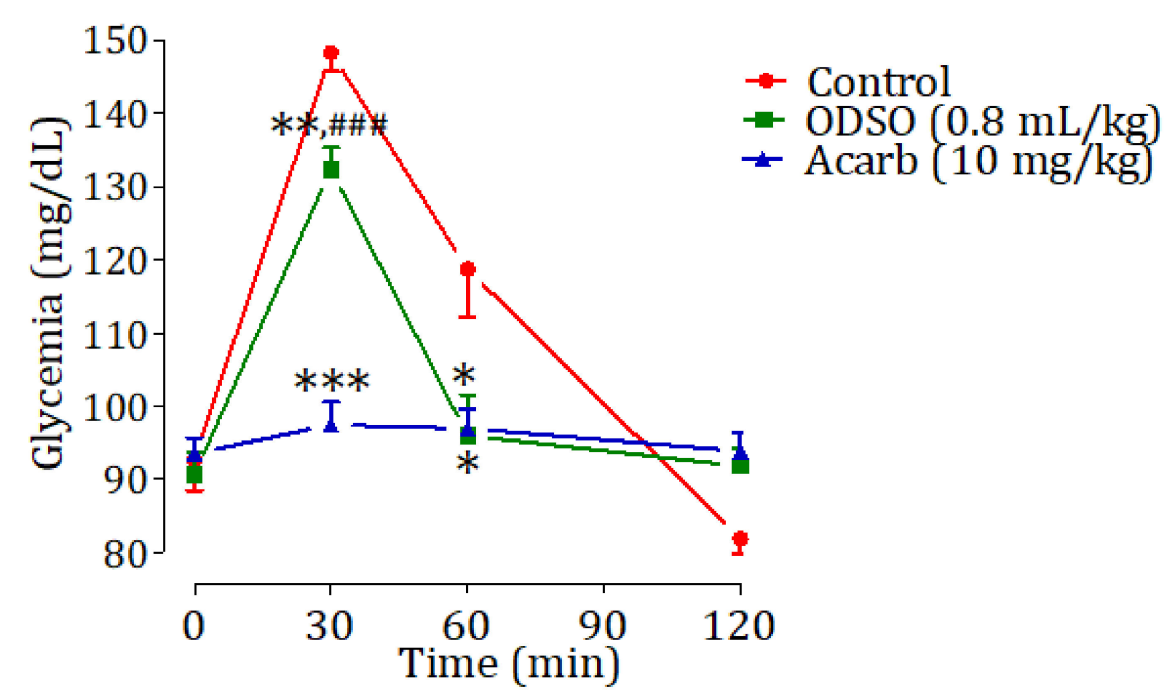

(B)

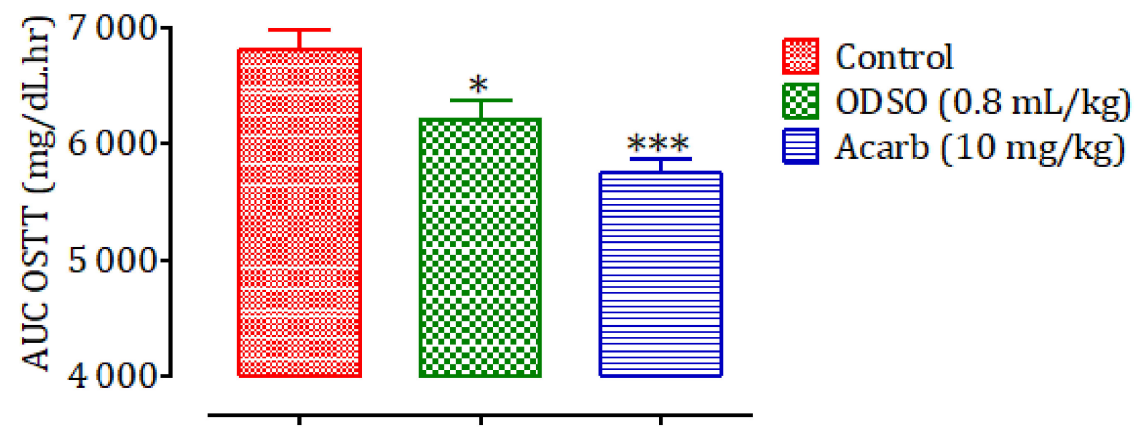

Figure 7. Effect of ODSO and acarbose on the change in the postprandial glycemia in normal rats (A), with a representation of the area under the curves (B). ODSO: Opuntia dillenii seed oil. The values are the means $\pm \operatorname{SEM}(n=6) .{ }^{*} p<0.05,{ }^{* *} p<0.01$, and ${ }^{* * *} p<0.001$ compared to the control and \#\#\# $p<0.00$ : compared to the acarbose group. 


\subsubsection{Diabetic Rats}

The oral administration of ODSO at $0.8 \mathrm{~mL} / \mathrm{kg} 30 \mathrm{~min}$ before the starch overload in diabetic rats significantly reduced the postprandial hyperglycemia to $30 \mathrm{~min}(p<0.01$; $162 \pm 12 \mathrm{mg} / \mathrm{dL})$ and $60 \mathrm{~min}(p<0.001 ; 169 \pm 10 \mathrm{mg} / \mathrm{dL})$. At $120 \mathrm{~min}$, the effect of the oil was not significant $(176 \pm 10 \mathrm{mg} / \mathrm{dL})$ in comparison with the group of rats pretreated with distilled water in which the starch overload-induced remarkable hyperglycemia was observed: at $30 \mathrm{~min}(182 \pm 10 \mathrm{mg} / \mathrm{dL}), 60 \mathrm{~min}(201 \pm 10 \mathrm{mg} / \mathrm{dL})$, and $120 \mathrm{~min}(186 \pm 7 \mathrm{mg} / \mathrm{dL})$. Similarly, acarbose significantly inhibited the postprandial hyperglycemia during the two hours following the starch overload at $30 \mathrm{~min}(p<0.001$; $122 \pm 7 \mathrm{mg} / \mathrm{dL}), 60 \mathrm{~min}(p<0.001 ; 106 \pm 6 \mathrm{mg} / \mathrm{dL})$, and $120 \mathrm{~min}(p<0.01 ; 105 \pm 4 \mathrm{mg} / \mathrm{dL})$ compared with the group of rats pretreated with distilled water. Moreover, the comparison of the effect of ODSO with that of acarbose showed that there was a significant difference between them at $30 \mathrm{~min}, 60 \mathrm{~min}$, and $120 \mathrm{~min}$ (Figure 8A). The area under the curve (AUC D-glucose) was significantly $(p<0.001)$ lower in rats treated with ODSO $(9862 \pm 595$ $\mathrm{mg} / \mathrm{dL} / \mathrm{h})$ than that of rats treated with distilled water $(11,017 \pm 399 \mathrm{mg} / \mathrm{dL} / \mathrm{h})$. Additionally, the curve area of acarbose was significantly $(p<0.001)$ low $(67.93 \pm 2.64 \mathrm{mg} / \mathrm{dL} / \mathrm{h})$ compared to the area under the curve of water-treated rats. Moreover, there was a significant $(p<0.001)$ difference between the area under the curves of the ODSO and acarbose groups (Figure 8B).

(A)

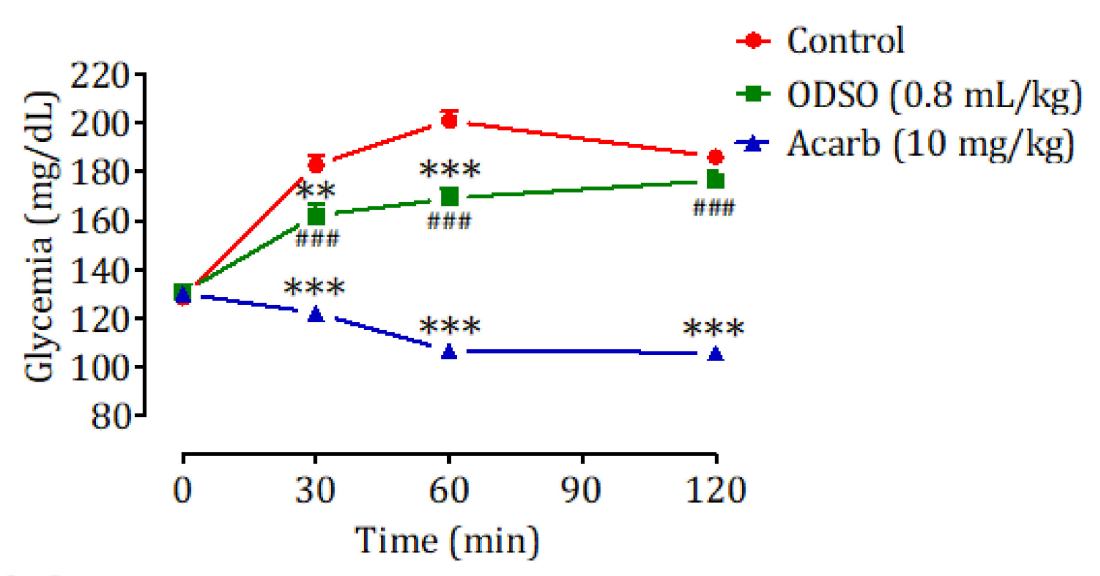

(B)

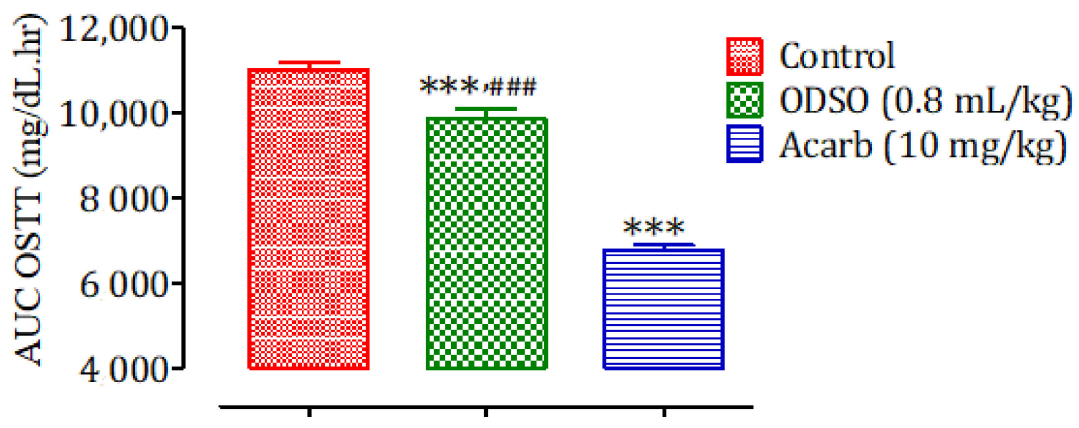

Figure 8. Effect of ODSO and acarbose on the change in the postprandial glycemia in diabetic rats (A), with a representation of the area under the curves (B). ODSO: Opuntia dillenii seed oil. The values are the means $\pm \operatorname{SEM}(n=6) .{ }^{* *} p<0.01$ and ${ }^{* * *} p<0.001$ compared to the control and ${ }^{\# \# \#} p<0.001$ compared to the acarbose group. 


\subsection{Inhibition Assay of Intestinal $\alpha$-Glucosidase Activity In Vitro}

The results of the effect of ODSO on the activity of intestinal $\alpha$-glucosidase in vitro are shown in Figure 9. Indeed, the activity of the intestinal $\alpha$-glucosidase enzyme was significantly $(p<0.001)$ inhibited in the presence of ODSO compared to the test control. The inhibitory effect of the intestinal $\alpha$-glucosidase activity was proportional to the ODSO concentration, with an $\mathrm{IC}_{50}=278 \pm 0.01 \mu \mathrm{g} / \mathrm{mL}$ compared with the control test. Besides, this inhibitory effect of intestinal $\alpha$-glucosidase by ODSO was significantly $(p<0.001)$ lower than that of acarbose $\left(\mathrm{IC}_{50}=203 \pm 33 \mathrm{mg} / \mathrm{mL}\right)$.

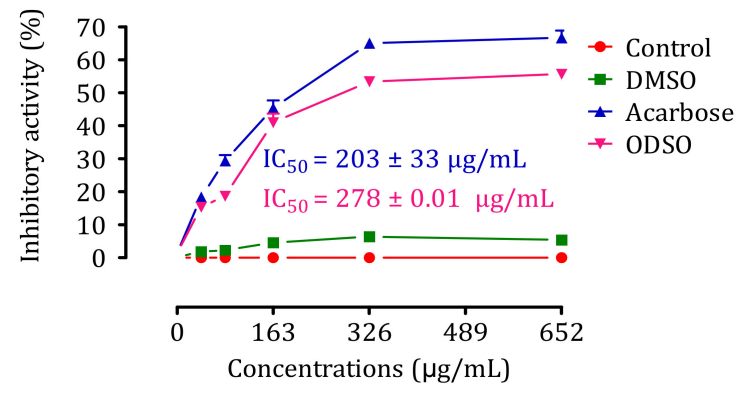

Figure 9. Inhibitory effect of the intestinal $\alpha$-glucosidase activity by ODSO and acarbose in vitro. The values are the means $\pm \operatorname{SEM}(n=3)$. ODSO: Opuntia dillenii seed oil.

\subsection{Kinetics of Intestinal $\alpha$-Glucosidase Inhibition In Vitro}

The results in Figure 10 show that the D-glucose release rate decreases in the presence of $165-\mu \mathrm{g} / \mathrm{mL}$ ODSO and continues to decrease after increasing the ODSO dose to $325 \mu \mathrm{g} / \mathrm{mL}$ compared to the control (Figure 10A). To characterize the inhibition process of ODSO against $\alpha$-glucosidase, the results were analyzed using Lineweaver-Burk waveforms. In Figure 10B, the intersection of the three lines on the horizontal axis showed that ODSO exerts a noncompetitive reversible mode inhibitor effect on the intestinal $\alpha$-glucosidase enzyme in vitro. The type of noncompetitive reversible inhibition indicates that the change in substrate concentration will not affect the inhibition rate. The $\mathrm{Km}$ and Vmax values are shown in Table 1.

\section{(A)}

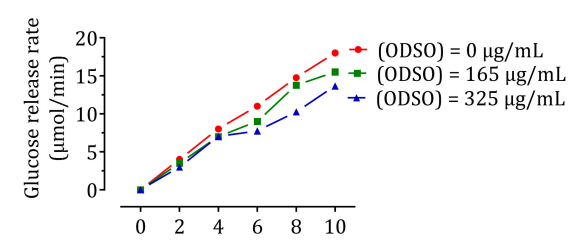

(B)

Concentration $(\mu \mathrm{g} / \mathrm{mL})$

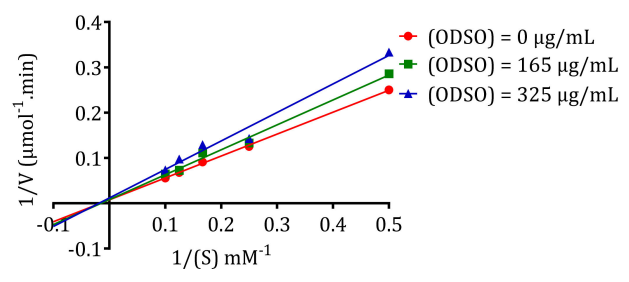

Figure 10. Kinetics of the intestinal $\alpha$-glucosidase inhibition by ODSO: (A) the D-glucose release rate as a function of the sucrose concentration. (B) Lineweaver-Burk graph for the kinetic analysis of the intestinal $\alpha$-glucosidase inhibition by ODSO. ODSO: Opuntia dillenii seed oil. 
Table 1. Kinetics parameters of $\alpha$-glucosidase inhibition by Opuntia dillenii seed oil (ODSO).

\begin{tabular}{ccc}
\hline $\begin{array}{c}\text { ODSO Concentration } \\
(\mu \mathrm{g} / \mathrm{mL})\end{array}$ & Km $(\mathbf{m M})$ & Vmax $(\mu \mathrm{M} / \mathbf{m i n})$ \\
\hline 0 & 71.42 & 166.66 \\
165 & 71.42 & 166.66 \\
325 & 71.42 & 83.3 \\
\hline
\end{tabular}

\subsection{Inhibition Assay of Intestinal $\alpha$-Glucosidase Activity in Nondiabetic and Diabetic Rats}

\subsubsection{Nondiabetic Rats}

The oral administration of ODSO at $0.8 \mathrm{~mL} / \mathrm{kg} 30 \mathrm{~min}$ prior to the sucrose overload in nondiabetic rats significantly reduced the postprandial hyperglycemia at $30 \mathrm{~min}(p<0.01$; $109 \pm 4 \mathrm{mg} / \mathrm{dL}), 60 \mathrm{~min}(p<0.01 ; 108 \pm 5 \mathrm{mg} / \mathrm{dL})$, and $120 \mathrm{~min}(p<0.05 ; 104 \pm 4 \mathrm{mg} / \mathrm{dL})$ compared with the group of rats pretreated with distilled water in which the sucrose overload-induced remarkable hyperglycemia was observed: at $30 \mathrm{~min}(140 \pm 6 \mathrm{mg} / \mathrm{dL})$, $60 \mathrm{~min}(150 \pm 10 \mathrm{mg} / \mathrm{dL})$, and $120 \mathrm{~min}(135 \pm 9 \mathrm{mg} / \mathrm{dL})$. Similarly, acarbose significantly inhibited the postprandial hyperglycemia during the two hours following the sucrose overload at $30 \mathrm{~min}(p<0.001 ; 99 \pm 4 \mathrm{mg} / \mathrm{dL}), 60 \mathrm{~min}(p<0.001 ; 110 \pm 6 \mathrm{mg} / \mathrm{dL})$, and $120 \mathrm{~min}$ $(p<0.001 ; 106 \pm 5 \mathrm{mg} / \mathrm{dL})$ compared with the group of rats pretreated with distilled water. Moreover, the comparison of the effect of ODSO with that of acarbose showed that there was no significant difference between them at $30 \mathrm{~min}, 60 \mathrm{~min}$, and $120 \mathrm{~min}$ (Figure 11A). The area under the curve (AUC D-glucose) was significantly $(p<0.01)$ lower in rats treated with ODSO $(6281 \pm 661 \mathrm{mg} / \mathrm{dL} / \mathrm{h})$ than in rats treated with distilled water $(8110 \pm 1038$ $\mathrm{mg} / \mathrm{dL} / \mathrm{h})$. Besides, the area under the curve of acarbose was significantly $(p<0.01)$ lower $(6205 \pm 473 \mathrm{mg} / \mathrm{dL} / \mathrm{h})$ compared to the area under the curve of the water-treated rats $(8110 \pm 1038 \mathrm{mg} / \mathrm{dL} / \mathrm{h})$. Moreover, there was no significant difference between the area under the curves of the ODSO and acarbose groups (Figure 11B).

\section{(A)}

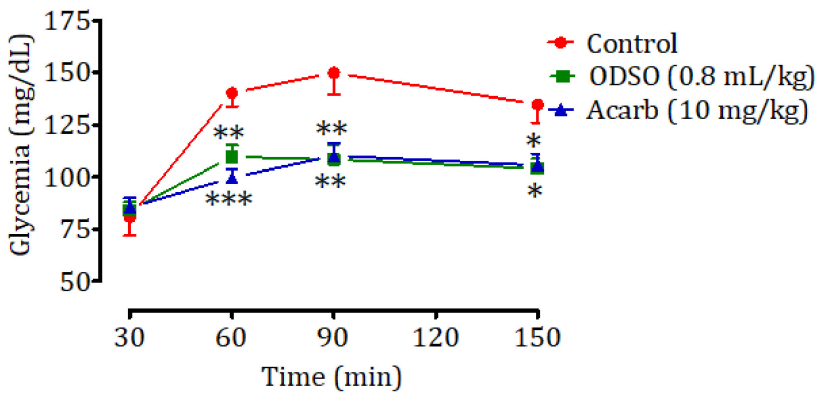

(B)

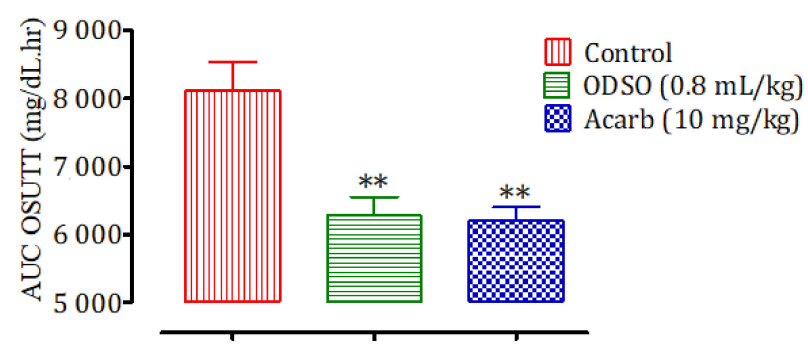

Figure 11. Effect of oil (ODSO) and acarbose (Acarb) on the change in the postprandial glycemia in normal rats (A), with a representation of the area under the curves (B). The values are the means $\pm \operatorname{SEM}(n=6) .{ }^{*} p<0.05,{ }^{* *} p<0.01$, and ${ }^{* * *} p<0.001$ compared to the control. 


\subsubsection{Diabetic Rats}

The oral administration of ODSO at $0.8 \mathrm{~mL} / \mathrm{kg} 30 \mathrm{~min}$ before the sucrose overload in diabetic rats significantly reduced the postprandial hyperglycemia at $30 \mathrm{~min}(p<0.001$; $226 \pm 9 \mathrm{mg} / \mathrm{dL}), 60 \mathrm{~min}(p<0.001 ; 232 \pm 9 \mathrm{mg} / \mathrm{dL})$, and $120 \mathrm{~min}(p<0.01 ; 223 \pm 14 \mathrm{mg} / \mathrm{dL})$ compared with the group of rats pretreated with distilled water in which the sucrose overload-induced remarkable hyperglycemia was observed: at $30 \mathrm{~min}(367 \pm 14 \mathrm{mg} / \mathrm{dL})$, $60 \mathrm{~min}(393 \pm 13 \mathrm{mg} / \mathrm{dL})$, and $120 \mathrm{~min}(421 \pm 32 \mathrm{mg} / \mathrm{dL})$. Similarly, acarbose significantly inhibited the postprandial hyperglycemia during the two hours following the sucrose overload at $30 \mathrm{~min}(p<0.001 ; 194 \pm 16 \mathrm{mg} / \mathrm{dL}), 60 \mathrm{~min}(p<0.001 ; 231 \pm 19 \mathrm{mg} / \mathrm{dL})$, and $120 \mathrm{~min}(p<0.01 ; 222 \pm 24 \mathrm{mg} / \mathrm{dL})$ compared with the group of rats pretreated with distilled water. Moreover, the comparison of the effect of ODSO with that of acarbose showed that there was a significant difference between them at $30 \mathrm{~min}, 60 \mathrm{~min}$, and 120 min (Figure 12A). The area under the curve (AUC D-glucose) was significantly $(p<0.05)$ lower in rats treated with ODSO $(2712 \pm 2886 \mathrm{mg} / \mathrm{dL} / \mathrm{h})$ than in rats treated with distilled water $(44,618 \pm 8466 \mathrm{mg} / \mathrm{dL} / \mathrm{h})$. Additionally, the area under the curve of acarbose was significantly $(p<0.05)$ low $(25,396 \pm 4494 \mathrm{mg} / \mathrm{dL} / \mathrm{h})$ compared to the area under the curve of water-treated rats $(44,618 \pm 8466 \mathrm{mg} / \mathrm{dL} / \mathrm{h})$. Moreover, there was no significant difference between the area under the curves of the ODSO and acarbose groups (Figure 12B).

\section{(A)}

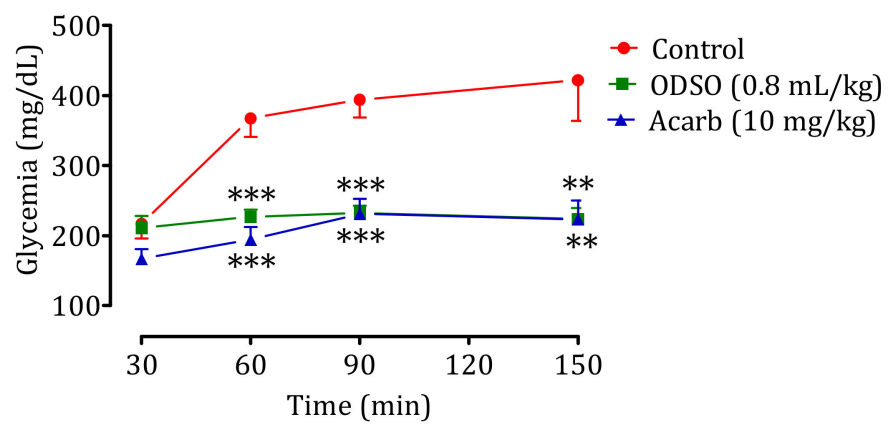

\section{(B)}

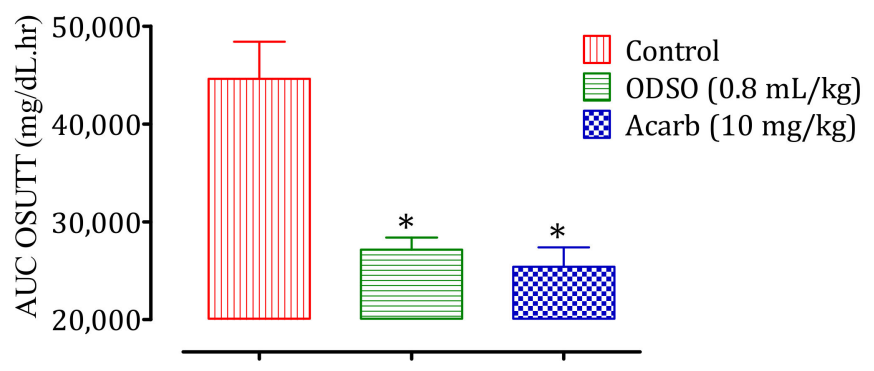

Figure 12. Effect of oil (ODSO) and acarbose (Acarb) on the change in the postprandial glycemia in diabetic rats (A), with a representation in the form of the area under the curve $(\mathbf{B})$. The values are the means $\pm \operatorname{SEM}(n=6) .{ }^{*} p<0.05,{ }^{* *} p<0.01$, and ${ }^{* * *} p<0.001$ compared to the control.

\section{Discussion}

Hyperglycemia is the most important feature of DM [40]. The rise of D-glucose in the blood generates oxygen-free radicals through D-glucose auto-oxidation [41] and also induces an increase in the serum levels of advanced glycation products [42]. The lack of control of postprandial hyperglycemia in diabetic patients will lead to the development of 
severe macro- and microvascular complications [43]. Therefore, controlling this biochemical parameter is a crucial therapeutic step in diabetic patients.

Under normal conditions, postprandial blood D-glucose is linked to two processes: the transformation of long-chain sugars into absorbable units and the intestinal absorption of these carbohydrate units. After a meal, polysaccharides are subjected to the action of $\alpha$-amylase to transform them into oligosaccharides, and then, the action of intestinal $\alpha$-glucosidase in the final phase is to give absorbable monosaccharides. To reach the blood, these monosaccharides are transported through the SGLT1 located in the brush border membrane (BBM) to the absorbing epithelial cells. Then, with the aid of the facilitated diffusion (GLUT2) located on the basolateral membrane (BLM) of the epithelial cells, they will cross into the blood [44].

One of the targeted pathways for treating DM is the food digestion route-more specifically, the inhibition of sugar-digesting enzymes such as intestinal $\alpha$-glucosidase and pancreatic $\alpha$-amylase and, also, a slowing of the intestinal absorption of D-glucose and a decrease in postprandial D-glucose [45]. The inhibition of digestive enzymes by naturally occurring sources could delay digestion and, thus, decrease D-glucose uptake [46].

In this study, the effect of the oil of Opuntia dillenii seeds on postprandial hyperglycemia was studied, and the exploration of its mechanisms of action was realized. The obtained results in our work showed, for the first time, that ODSO could improve Dglucose tolerance by controlling postprandial hyperglycemia caused by D-glucose overload. Indeed, the oral administration of ODSO has a significant antihyperglycemic effect in nondiabetic and streptozotocin (STZ)-diabetic rats overloaded with D-glucose. This effect was statically similar to that of glibenclamide. ODSO inhibited the liberated D-glucose intestinal absorption in situ; this inhibitory effect of the intestinal absorption of D-glucose was lower than that of phlorizin (a specific inhibitor of intestinal SGLT2). Moreover, ODSO blocked the intestinal passage of glucose by blocking the transporter SGLT1. While this oil does not show any risk of hypoglycemia on the basal glycemia in healthy rats fasted overnight, glibenclamide, on the other hand, shows a risk of hypoglycemia in nondiabetic rats. Glibenclamide is associated with a higher risk of hypoglycemia in seniors under routine care [47]. The results obtained about the ODSO effect agree with those found by Berraaouan et al. (2014) [34]. They showed that Opuntia ficus-indica seed oil has an antihypoglycemic effect, and they explained experimentally that this effect could be related to blocking the passage of D-glucose from the intestine to the bloodstream. Besides, ODSO inhibited the sucrose degradation by intestinal $\alpha$-glucosidase and the starch degradation by pancreatic $\alpha$-amylase in vitro and in vivo. In general, the effect of ODSO remains lower than that of acarbose, which is a powerful and specific inhibitor of these digestive enzymes. Therefore, the antihyperglycemic effect might be related to these effects. The acute toxicity test showed that the oil is not toxic, even at $7 \mathrm{~mL} / \mathrm{kg}$.

It has been declared that the oil of Opuntia dillenii contains a large amount of unsaturated fatty acids, wherein linoleic acid is the major polyunsaturated fatty acid and oleic acid is the main monounsaturated fatty acid. Furthermore, $\beta$-sitosterol is the sterol marker, and the unsaponifiable fraction was represented by only $\gamma$-tocopherol $[48,49]$. The oil from Opuntia seeds has been found to have an antihyperglycemic effect $[34,50]$. The phytosterols were found to have an important inhibitory effect on the pancreatic $\alpha$-amylase and intestinal $\alpha$-glucosidase activities [50-53]. Additionally, phytosterols are characterized by the property of increased peripheral use of D-glucose and stimulated insulin secretion $[54,55]$.

Insulin resistance and/or insulin deficiency are the two major defects that cause hyperglycemia in patients with diabetes [56]. The pancreatic $\beta$ cell increases its insulin secretion when stimulated by D-glucose under the effect of omega-3 fatty acids [57]. Besides, the fluidity of the cell membrane and the regulation of the GLUT4 transporter expression is improved by the polyunsaturated fatty acids [58]. The letters raise the amount of glucose absorbed by 3T3-L1 adipocytes by raising the number of GLUT4 and GLUT1 transporters [59]. $\beta$-sitosterol was found to exhibit significant hypoglycemic activity in normal and hyperglycemic models [60]. 
Another study reported that ODSO is rich in phenolic compounds, and 11 phenolic compounds were identified: catechol, cinnamic acid, phenyl propionic acid, psoralen, syringic acid, sinapaldehyde, $3^{\prime}$-O-methylcatechin, (+)-gallocatechin, bisdemethoxycurcumin, 4'-O-methyl-(-)-epicatechin 3'-O-glucuronide, and viscutin 1 [48]. Another mechanism proposed was the inhibition of key enzymes of carbohydrate metabolism, $\alpha$-glucosidase, and $\alpha$-amylase by the phenolic compounds present in ODSO [61,62]. These phenolic compounds, which are characterized by antioxidant activity, are known to have antidiabetic activity by regulating the disturbed oxidative medium under diabetic conditions $[63,64]$. It has been reported that antioxidants protect the sensitivity of L6 muscle cells from insulin [65]. From these data, it can be concluded that the antihyperglycemia effect of ODSO is related to its richness in natural bioactive compounds that have a very important antidiabetic property while reacting alone or in synergy.

The oil extraction yielded $7 \%$, and this was close to the extractions achieved by other studies. Labuschagne and Hugo [66] reported that the oil content in Cactus Opuntia dillenii seeds from South Africa was 5.69\%, while Chang [67] reported that the oil content in Cactus pear seed oil from China was $6.01 \%$. The two results were close to the obtained results from the present study. However, the oil content from an Italian cultivar was 9.14\% [68], and the oil content was $11.05 \%$ from another cultivar from Tunisia [69]. Compared to other oil seed crops, Opuntia dillenii presented a lower oil content. Indeed, higher amounts were recovered from cotton seeds (15-24\%), soybean seeds (17-21\%), grape seeds $(6-20 \%)$, and olives $(20-25 \%)$ [70].

\section{Materials and Methods}

\subsection{Chemicals and Reagents}

The following drugs and solvents were used in this study: D-(+)-glucose anhydrous, sucrose, starch, and phlorizin hydrate were purchased from Sigma Aldrich (Riedel-de Haen, Germany). Glibenclamide, dimethyl-sulfoxide, acarbose, $\alpha$-glucosidase, and $\alpha$-amylase were purchased from Sigma Aldrich ( St. Louis, MO, USA); streptozotocin was purchased from Sigma-Aldrich (Hamburg, Germany); sodium pentobarbital was purchased from Ceva Santé Animale (Libourne, France); and the glucose oxidase-peroxidase (GOD-POD) kit necessary for the measurement of blood sugar was purchased from Biosystems (Barcelona, Spain). All chemicals were of analytical grade.

\subsection{Opuntia Dillenii Fruit Harvest}

The fresh fruit from Opuntia dillenii used in this study was collected in February 2018 in the Essaouira city Morocco. After its identification by an expert botanist, Mohammed Fennan, from the Scientific Institute of Mohammed 5 University, Rabat, the specimen was deposited at Mohammed First University, Oujda, Morocco, under voucher code HUMPOM 351.

\subsection{Powder Preparation and Oil Extraction of Opuntia dillenii Seeds}

The fruits of Opuntia dillenii were peeled, and then, the seeds were separated from the fruit, cleaned with distilled water, oven-dried at $37^{\circ} \mathrm{C}$ for three days, and then crushed until a fine and homogeneous powder was obtained. A quantity of $100 \mathrm{~g}$ of powder from the seeds of Opuntia dillenii was added to $500 \mathrm{~mL}$ of petroleum ether, and then, the mixture was agitated for $24 \mathrm{~h}$ at room temperature. After filtration, a rotary evaporator was used to remove the organic solvent at $40^{\circ} \mathrm{C}$. The resulting oil was dried and stored at $4{ }^{\circ} \mathrm{C}$.

\subsection{Experimental Animals}

The present study was conducted by using normal adult Wistar rats and Swiss albinos mice from the local animal husbandry of the faculty of Science, Mohammed First University, Oujda, Morocco. The animals were grouped in polycarbonate cages with soft bedding and ad libitum water and food access in an environmentally controlled room $\left(22-26^{\circ} \mathrm{C}\right.$, with a $12 / 12$-h photoperiod). All rats were cared for in compliance with the internationally 
accepted Guide for the care and use of laboratory animals, published by the US National Institutes of Health, 2011 [71].

\subsection{Acute Oral Toxicity in Mice}

Opuntia dillenii seeds oil acute oral toxicity was evaluated using albinos mice (22-32 g body weight, 1.5-2 months of age). Thirty fasted $(14 \mathrm{~h})$ mice were put into five groups ( 3 males and 3 females in separate cages), then treated orally by different concentrations of $\operatorname{ODSO}(1,3,5$, and $7 \mathrm{~mL} / \mathrm{kg})$ for the test groups or distilled water $(10 \mathrm{~mL} / \mathrm{kg})$ for the control group. Signs of toxic effects and/or mortality were observed after $2 \mathrm{~h}$ and every $24 \mathrm{~h}$ during the 14 days after administration.

\subsection{Hypoglycemic Test in Nondiabetic Rats}

This test was carried out according to the method described by Bellahcen et al. (2012) [72]. Normal rats (190-260 g b.w., 2 to 3 months of age) fasted for $14 \mathrm{~h}$ with free access to water were used in this test. Animals were arranged into three groups ( 3 males and 3 females in separate cages). The ODSO group received a single per os seed oil dose ( $2 \mathrm{~mL} / \mathrm{kg}$ b.w.), the glibenclamide group (Glib) received a single per os glibenclamide (an antidiabetic drug that acts directly on pancreatic beta cells to induce insulin secretion [73]) oral dose ( $2 \mathrm{mg} / \mathrm{kg}$ b.w.), and the control group received distilled water at a dose of (10 mL/kg b.w.). Treated rats glycemic index was measured before and 30, 60, 120, 240, and $360 \mathrm{~min}$ after product administration. After the test, the animals were subjected to unlimited access to food and water in a controlled room and monitored for two hours after, until blood sugar returned to the normal physiological status.

\subsection{Induction of Experimental Diabetes}

Streptozotocin (STZ; Sigma-Aldrich, Hamburg, Germany) recently prepared in a citrate buffer (0.1-M citrate and 0.1-M phosphate, $\mathrm{pH} 4.5$ ) was injected intraperitoneally into rats (fasted overnight) by a single dose $(60 \mathrm{mg} / \mathrm{kg})$ to induce experimental diabetes (diabetes mellitus [74]). However, the animals were hydrated with glucose water during the days following the injection to avoid hypoglycemic seizures and death. Rats with fasting (14 h) blood D-glucose greater than or equal to $150 \mathrm{mg} / \mathrm{dL}$ on the seventh day after injection, indicating polydipsia and polyuria, were regarded as diabetic and incorporated into the study.

\subsection{Antihyperglycemic Study in Nondiabetic and Diabetic Rats}

Both normal and diabetic fasted rats $(14 \mathrm{~h})$ were randomly divided into three groups (3 males and 3 females in separate cages). Indeed, healthy and diabetic rat control groups received distilled water at a dose of $10 \mathrm{~mL} / \mathrm{kg}$ b.w. ODSO groups received the oil at a dose of $0.8-\mathrm{mL} / \mathrm{kg}$ b.w. for nondiabetic rats and $1-\mathrm{mL} / \mathrm{kg}$ b.w. for diabetic rats (ODSO doses used in nondiabetic or diabetic rats were selected following the preliminary testing [34]). The minimum doses were 0.8 and $1 \mathrm{~mL} / \mathrm{kg}$ that induced a significant antihyperglycemic effect in normal and diabetic rats, respectively). The glibenclamide groups (Glib) received an antidiabetic drug, glibenclamide, at a dose of $2 \mathrm{mg} / \mathrm{kg}$ for healthy and diabetic rats. All the animals were orally loaded with D-glucose $(2 \mathrm{~g} / \mathrm{kg}) 30 \mathrm{~min}$ after intake of the testing product. Glycemia was measured at 0, 30, 90, 150, and $210 \mathrm{~min}$ by the glucose oxidase-peroxidase (GOD-POD) method. Indeed, plasma glucose was measured using a commercial enzyme assay kit. Blood was collected from the caudal artery of rats in heparin hematocrit tubes. These were centrifuged in a hematocrit centrifuge at $3000 \mathrm{rpm}$ for $10 \mathrm{~min}$. In a dosing tube, $1000 \mu \mathrm{L}$ of enzymatic reagent was added to the $10 \mu \mathrm{L}$ of plasma (Abs plasma) or $10 \mu \mathrm{L}$ of glucose $(1 \mathrm{~g} / \mathrm{L})$ (Abs standard), and then, the tube was agitated in the vortex and incubated at $37^{\circ} \mathrm{C}$ for $5 \mathrm{~min}$. The absorbance was read at $500 \mathrm{~nm}$ 
by a spectrophotometer. The concentration of glucose in $\mathrm{mg} / \mathrm{dl}$ was calculated by the following formula:

$$
\operatorname{Glycaemia}(m g / d l)=\frac{\text { Abs }(\text { plasma })}{\text { Abs }(\text { satndard })} \times 100
$$

After the test, the animals were subjected to unlimited access to food and water in a controlled room and monitored for two hours, until their blood sugar returned to a normal physiological state. For diabetic rats, they were monitored by insulin injection.

\subsection{Single-Pass Intestinal Perfusion in Rats}

The effect of ODSO on the intestinal absorption of D-glucose in normal rats was tested using the in situ intestinal single-pass perfusion method [34]. Normal Wistar rats (140-300 g) fasted for $36 \mathrm{~h}$ were divided into 4 groups ( 3 males and 3 females in separate cages). The control group was perfused with the D-glucose perfusion solution $(1 \mathrm{~g} / \mathrm{kg})$. The Tween 20 group was perfused by the D-glucose perfusion solution $(1 \mathrm{~g} / \mathrm{kg})+$ Tween 20 $(1 \%)$. The ODSO group was perfused by the D-glucose perfusion solution $(1 \mathrm{~g} / \mathrm{kg})+$ ODSO $(1 \mathrm{~mL} / \mathrm{kg})$. Tween 20 is an agent that was used to solubilize the oil in the perfusion solution, and this group was added to show that this agent does not affect the intestinal absorption of glucose. The phlorizin group was perfused by the D-glucose perfusion solution $(1 \mathrm{~g} / \mathrm{kg})$ + phlorizin $(0.2 \mathrm{mM})$. Phlorizin is a competitive inhibitor of SGLT1, because it competes with D-glucose to bind to the carrier, and it reduces the intestinal absorption of glucose, lowering the amount of glucose in the blood [75]. At the end of the experiment, an aliquot of $0.5 \mathrm{~mL}$ of the perfusate recovered was taken for the D-glucose determination [76], the length of the perfused jejunal fragment was measured, and the rat (state-anesthetized by pentobarbital) was euthanized. The content of the absorbed D-glucose was expressed as the amount of absorbed D-glucose $(\mathrm{mg})$ by the length of the infused jejunum $(10 \mathrm{~cm})$ by the duration of infusion (60 min).

\subsection{Ussing Chamber Assay}

For this experiment, normal fasting mice $(16 \mathrm{~h})$ were used after cervical dislocation. The method used was described by Eto et al. [77]. The proximal jejunum (5-cm distal from the ligament of Treitz) was dissected and rinsed in cold saline solution. The mesenteric border was carefully stripped off using forceps. The intestine was then opened along the mesenteric border, and four adjacent proximal samples were placed between the two halves of the modified Ussing chambers (exposed area: $0.3 \mathrm{~cm}^{2}$ ). The tissues were bathed with $3 \mathrm{~mL}$ of carbogen-gassed Krebs-Ringer bicarbonate (KRB) solution on each side. KRB solution had the following composition (in $\mathrm{mM}$ ): $\mathrm{NaCl}, 115.4, \mathrm{KCl}, 5, \mathrm{MgCl}_{2}$, 1.2, $\mathrm{NaH}_{2} \mathrm{PO}_{4}, 0.6, \mathrm{NaHCO}_{3}, 25$, and $\mathrm{CaCl}_{2}$, 1.2. In the solution bathing the mucosal side of the tissue, D-glucose was replaced with mannitol. Both solutions were gassed with $95 \% \mathrm{O}_{2}$ and $5 \% \mathrm{CO}_{2}$ and kept at a constant temperature of $37 \pm 0.5^{\circ} \mathrm{C}(\mathrm{pH}$ at 7.4). Electrogenic glucose transport was monitored continuously as the short-circuit current (Isc) by using an automated voltage-clamp apparatus linked through MacLab 8 to a MacIntosh computer (Supplementary Materials Figure S1). The ODSO solution was prepared in Ringer's solution, and 5\% taurocholic acid was used to emulsify the oil in the Ringer. The solution was introduced into the mucosal bath in various concentrations $(1000,100,10,1$, and $0.1 \mu \mathrm{g} / \mathrm{mL})$ before the addition of luminal D-glucose; a concentration of $(1000 \mu \mathrm{g} / \mathrm{mL})$ was tested to determine whether or not ODSO was affected. The results were expressed as the difference between the Isc peak caused by glucose (measured after $20 \mathrm{~min}$ ) and the ISC measured only $5 \mathrm{~min}$ after adding the oil extract, followed by the addition of $50-\mu \mathrm{L}$ phlorizin (PHZ; $0.5 \mathrm{mM}$ ) in a unique concentration experience. The percentage of inhibition thus referred to the individual values calculated from the paired controls relative to D-glucose (100\%). The short-circuit current (Isc) represented the sum of the net ion flux transported across the epithelium [77]. 


\subsection{Inhibition Assay of $\alpha$-Amylase Activity In Vitro}

The $\alpha$-amylase inhibition activity by ODSO was studied according to the procedure described by Daoudi et al. [78], with some modifications. The assay mixtures contained 200 $\mu \mathrm{L}$ of $\alpha$-amylase enzyme solution (13 IU); $200 \mu \mathrm{L}$ of phosphate buffer $(0.02 \mathrm{M}$; $\mathrm{pH}=6.9$ ); and $200 \mu \mathrm{L}$ of ODSO $(6.67,5.26,3.90,2.56,1.27,0.63$, and $0.31 \mathrm{mg} / \mathrm{mL}$, solubilized in DMSO $(1 \%))$ and acarbose $(6.82,4.54,2.27,0.91,0.45,0.23,0.11$, and $0.06 \mathrm{mg} / \mathrm{mL})$; acarbose is a specific inhibitor of intestinal alpha-glucosidase and pancreatic alpha-amylase enzymes [79] and DMSO (1\%) is an agent that was used to solubilize the oil in the perfusion solution, and this group was added to show that this agent does not affect the intestinal absorption of glucose or distilled water (control). The mixtures were pre-incubated at $37^{\circ} \mathrm{C}$ for $10 \mathrm{~min}$. Then, $200 \mu \mathrm{L}$ of starch (1\%) dissolved in phosphate buffer was added to each tube and was incubated for $20 \mathrm{~min}$ at $37^{\circ} \mathrm{C}$. To stop the enzymatic reaction, $600 \mu \mathrm{L}$ of DNSA color reagent $(2.5 \%)$ was added. Right after, the tubes were incubated for $8 \mathrm{~min}$ at $100{ }^{\circ} \mathrm{C}$; then, they were put in an ice-cold water bath for a few minutes. The mixture was diluted by adding $1 \mathrm{~mL}$ of distillate water, and the absorbance was measured at $540 \mathrm{~nm}$. The inhibition percentage was calculated using the formula below:

$$
\text { Inhibitory activity percentage }=((\text { DO Control }- \text { DO Test }) / \text { DO Control }) \times 100
$$

where DO Control: Absorption of enzymatic activity without inhibitor; DO Test: Absorption of enzymatic activity in the presence of oil or acarbose.

\subsection{Inhibition Assay of $\alpha$-Amylase Activity in Normal and Diabetic Rats}

Nondiabetic and diabetic fasted rats were divided into three groups ( 3 males and 3 females in separate cages) for each model. The control groups received distilled water at a dose of $10 \mathrm{~mL} / \mathrm{kg}$, the ODSO groups received oil at a dose of $0.8 \mathrm{~mL} / \mathrm{kg}$, and the acarbose groups received acarbose at a dose of $10 \mathrm{mg} / \mathrm{kg}$ by oral gavage. All the animals were orally loaded with starch $(2 \mathrm{~g} / \mathrm{kg})$ at $30 \mathrm{~min}$ after treatments. Their blood was taken by the venous section of the tail from rats under light ether anesthesia at $0,30,60$, and 120 min to measure glycemia. After the test, the animals were subjected to unlimited access to food and water in a controlled room and monitored for two hours, until their blood sugar returned to a normal physiological state. For diabetic rats, they were monitored by insulin injection.

\subsection{Inhibition Assay of Intestinal $\alpha$-Glucosidase Activity In Vitro}

The effect of the ODSO against intestinal $\alpha$-glucosidase activity was quantified colorimetrically by monitoring the D-glucose release from sucrose degradation, according to the protocol described by Ouassou et al. [80], with some modifications. The assay mixtures contained $100 \mu \mathrm{L}$ of sucrose (50 Mm), $1000 \mu \mathrm{L}$ of phosphate buffer $(50 \mathrm{mM}$; $\mathrm{pH}=7.5)$, and $100 \mu \mathrm{L}$ of intestinal $\alpha$-glucosidase enzyme solution (10 IU). Ten microliters of distilled water (control, acarbose (Acarb), and ODSO solutions at different concentrations (40.75, $81.5,163,326$, and $652 \mu \mathrm{g} / \mathrm{mL}$ solubilized in DMSO $(1 \%)$ ) or DMSO $(1 \%)$ were added to the mixture. Then, it was incubated at $37{ }^{\circ} \mathrm{C}$ in a water bath for $25 \mathrm{~min}$. Then, the mixture was heated at $100{ }^{\circ} \mathrm{C}$ for $5 \mathrm{~min}$ to stop the enzymatic reaction, and the released D-glucose was estimated by the D-glucose oxidase method using a commercial auto-kit. The absorbance was measured at $500 \mathrm{~nm}$, and the inhibition percentage was calculated using the formula below:

$$
\text { Inhibitory activity percentage }=((\mathrm{DO} \text { control }-\mathrm{DO} \text { Test }) / \mathrm{DO} \text { control }) \times 100
$$

where DO Control: Absorption of enzymatic activity without inhibitor; DO Test: Absorption of enzymatic activity in the presence of oil or acarbose. 


\subsection{Kinetics of Intestinal $\alpha$-Glucosidase Inhibition In Vitro}

In this study, the type of inhibition of ODSO against intestinal $\alpha$-glucosidase was determined. Indeed, a constant concentration of intestinal $\alpha$-glucosidase was incubated with increasing amounts of its sucrose substrate $(2,4,6,8$, and $10 \mathrm{~mL} / \mathrm{L})$ in the presence or absence of two concentrations of ODSO (solubilized in DMSO (1\%)) (165 and $365 \mu \mathrm{g} / \mathrm{mL}$ ). The optimal dose used in this study was determined by testing the activity of this enzyme as described earlier and from a preliminary test of the kinetics of the intestinal $\alpha$-glucosidase inhibition. Moreover, the mode of inhibition of this oil was determined by analyzing the Lineweaver-Burk representation of the results, which was calculated from the results according to Michaelis-Menten kinetics [81].

\subsection{Inhibition Assay of Intestinal $\alpha$-Glucosidase Activity in Normal and Diabetic Rats}

Nondiabetic and diabetic fasted rats were regrouped into three groups ( 3 males and 3 females in separate cages) for each model. The control groups received distilled water at a dose of $10 \mathrm{~mL} / \mathrm{Kg}$, the ODSO groups received oil at the dose of $0.8 \mathrm{~mL} / \mathrm{kg}$, and the Acarb groups received acarbose at the dose of $10 \mathrm{mg} / \mathrm{kg}$ by oral gavage. All the animals were orally loaded with sucrose $(2 \mathrm{~g} / \mathrm{kg}) 30 \mathrm{~min}$ after treatments. Their blood was taken by the venous section of the tail from rats under light ether anesthesia at $0,30,60$, and $120 \mathrm{~min}$ to measure their glycemia. After the test, the animals were subjected to unlimited access to food and water in a controlled room and monitored for two hours, until their blood sugar returned to a normal physiological state. For diabetic rats, they were monitored by insulin injection.

\subsection{Statistical Analysis}

Data were presented as the mean \pm standard errors and were subjected to statistical analysis using GraphPad Prism 5 (GraphPad Software), San Diego, CA, USA. Multiplegroup comparisons were analyzed by one-way analysis of variance (ANOVA). Statistical significance was accepted as $p<0.05$.

\section{Conclusions}

This study first explored the mechanism of action of the antidiabetic effect of the ODSO. This oil exerted an antihyperglycemic effect in healthy and STZ-provoked diabetic rats. This effect was due, in part, to the inhibition of the intestinal $\alpha$-glucosidase and pancreatic $\alpha$-amylase enzymes, as well as the inhibition of intestinal D-glucose absorption. Further studies are needed to explore other pathways through which this antihyperglycemic effect passes.

Supplementary Materials: The following are available online, Figure S1: Ussing chamber assay.

Author Contributions: Conceptualization, M.B (Mohamed Bouhrim)., A.Z., H.M. (Hassan Mekhfi), A.L., M.A., and M.B. (Mohamed Bnouham); methodology, B.G. and B.E.; formal analysis, H.O., S.B., and N.E.D.; data curation, H.M. (Hamza Mechchate) and H.I.; writing-original draft preparation, M.B. (Mohamed Bouhrim), H.O., and S.B.; writing-review and editing, A.A.A. and M.A.-z.; and supervision, M.B (Mohamed Bnouham). All authors have read and agreed to the published version of the manuscript.

Funding: This research was funded by the Deanship of Scientific Research at Princess Nourah bint Abdulrahman University through the Fast-track Research Funding Program.

Institutional Review Board Statement: The study was conducted according to the guidelines of the Declaration of Helsinki and approved by the Institutional Review Board of the Faculty of Sciences, Oujda, Morocco (11/19-LBBEH-08 and 05/11/2019).

Informed Consent Statement: Not applicable.

Data Availability Statement: The data presented in this study are available on request from the corresponding author. 
Acknowledgments: The authors extend their appreciation to the Deanship of Scientific Research at Princess Nourah bint Abdulrahman University for funding this work through the Fast-track Research Funding Program.

Conflicts of Interest: The authors declare no conflict of interest.

Sample Availability: Sample are available from the authors upon reasonable request.

\section{References}

1. Fajardo, S.; García-Galvan, R.F.; Barranco, V.; Galvan, J.C.; Batlle, S.F. A Review of the Antidiabetic Activities of Ginge; Intech Open Limited: London, UK, 2016.

2. Bi, X.; Lim, J.; Henry, C.J. Spices in the management of diabetes mellitus. Food Chem. 2017, 217, 281-293. [CrossRef] [PubMed]

3. IDF Diabetes Atlas, 9th ed.; International Diabetes Federation: Brussels, Belgium, 2019; ISBN 978-2-930229-87-4.

4. Saeedi, P.; Petersohn, I.; Salpea, P.; Malanda, B.; Karuranga, S.; Unwin, N.; Colagiuri, S.; Guariguata, L.; Motala, A.A.; Ogurtsova, K.; et al. Global and regional diabetes prevalence estimates for 2019 and projections for 2030 and 2045: Results from the International Diabetes Federation Diabetes Atlas, 9th edition. Diabetes Res. Clin. Pract. 2019, 157, 107843. [CrossRef] [PubMed]

5. Pheiffer, C.; Wyk, V.P.-V.; Joubert, J.D.; Levitt, N.; Nglazi, M.D.; Bradshaw, D. The prevalence of type 2 diabetes in South Africa: A systematic review protocol. BMJ Open 2018, 8, 21-29. [CrossRef]

6. Avogaro, A.; Fadini, G.P. The Effects of Dipeptidyl Peptidase-4 Inhibition on Microvascular Diabetes Complications. Diabetes Care 2014, 37, 2884-2894. [CrossRef]

7. Le Marchand-Brustel, Y.; Jeanrenaud, B.; Freychet, P. Insulin binding and effects in isolated soleus muscle of lean and obese mice. Am. J. Physiol. Metab. 1978, 234, E348. [CrossRef] [PubMed]

8. Sheard, N.F.; Clark, N.G.; Brand-Miller, J.C.; Franz, M.J.; Pi-Sunyer, F.X.; Mayer-Davis, E.; Kulkarni, K.; Geil, P. Dietary Carbohydrate (Amount and Type) in the Prevention and Management of Diabetes: A statement by the American Diabetes Association. Diabetes Care 2004, 27, 2266-2271. [CrossRef] [PubMed]

9. Sales, P.M.; Souza, P.M.; Simeoni, L.A.; Magalhães, P.O.; Silveira, D. $\alpha$-Amylase Inhibitors: A Review of Raw Material and Isolated Compounds from Plant Source. J. Pharm. Pharm. Sci. 2012, 15, 141-183. [CrossRef]

10. Olaokun, O.O.; McGaw, L.J.; Eloff, J.N.; Naidoo, V. Evaluation of the Inhibition of Carbohydrate Hydrolysing Enzymes, Antioxidant Activity and Polyphenolic Content of Extracts of Ten African Ficus Species (Moraceae) Used Traditionally to Treat Diabetes. BMC Complementary Altern. Med. 2013, 13, 94. [CrossRef] [PubMed]

11. Hui, H.; Zhao, X.; Perfetti, R. Structure and function studies of glucagon-like peptide-1 (GLP-1): The designing of a novel pharmacological agent for the treatment of diabetes. Diabetes Metbal Res. Rev. 2005, 21, 313-331. [CrossRef]

12. Bathaie, S.Z.; Mokarizade, N.; Shirali, S. An Overview of the Mechanisms of Plant Ingredients in the Treatment of Diabetes Mellitus. J. Med. Plants 2012, 11, 1-24.

13. Kooti, W.; Farokhipour, M.; Asadzadeh, Z.; Ashtary-Larky, D.; Asadi-Samani, M. The role of medicinal plants in the treatment of diabetes: A systematic review. Electron. Phys. 2016, 8, 1832-1842. [CrossRef]

14. Es-Safi, I.; Mechchate, H.; Amaghnouje, A.; El Moussaoui, A.; Cerruti, P.; Avella, M.; Grafov, A.; Bousta, D. Marketing and legal status of phytomedicines and food supplements in Morocco. J. Complement. Integr. Med. 2020. [CrossRef]

15. Schlienger, J.-L. Diabète et Phytothérapie: Les Faits. Méd. Mal. Métaboliques 2014, 8, 101-106. [CrossRef]

16. Koski, R.R. Practical Review of Oral Antihyperglycemic Agents for Type 2 Diabetes Mellitus. Diabetes Educ. 2006, 32, 869-876. [CrossRef]

17. Furman, B.L.; Candasamy, M.; Bhattamisra, S.K.; Veettil, S.K. Reduction of blood glucose by plant extracts and their use in the treatment of diabetes mellitus; discrepancies in effectiveness between animal and human studies. J. Ethnopharmacol. 2020, 247, 112264. [CrossRef] [PubMed]

18. Marles, R.J. Plants as Sources of Antidiabetic Agents. Econ. Med. Plant Res. 1994, 6, 149-187.

19. Chopra, A.; Saluja, M.; Tillu, G. Ayurveda-modern medicine interface: A critical appraisal of studies of Ayurvedic medicines to treat osteoarthritis and rheumatoid arthritis. J. Ayurveda Integr. Med. 2010, 1, 190-198. [CrossRef]

20. Reyes-Agüero, J.A.; Aguirre-Rivera, J.R.; Hernández, H.M. Notas Sistemáticas y Una Descripción Detallada de Opuntia Ficus-Indica (L.) Mill. (Cactaceae). Agrociencia 2005, 39, 395-408. (In Spanish)

21. Griffith, M.P. The origins of an important cactus crop, Opuntia ficus-indica (Cactaceae): New molecular evidence. Am. J. Bot. 2004, 91, 1915-1921. [CrossRef]

22. Hegwood, D.A. Human Health Discoveries with Opuntia sp. (Prickly Pear). HortScience 1990, 25, 1515-1516. [CrossRef]

23. Enigbokan, M.A.; Felder, T.B.; Thompson, J.O.; Kuti, J.O.; Ekpenyong, K.I. Hypoglycaemic Effects of Opuntia ficus-indica Mill., Opuntia lindheimeri Engelm and Opuntia robusta Wendl. in Streptozotocin-induced Diabetic Rats. Phytother. Res. 1996, 10, 379-382. [CrossRef]

24. Barbera, G.; Inglese, P.; Pimienta-Barrios, E. Agro-Ecology, Cultivation and Uses of Cactus Pear; FAO: Rome, Italy, 1995; Volume 132.

25. Keter, L.K.; Mutiso, P.C. Ethnobotanical studies of medicinal plants used by Traditional Health Practitioners in the management of diabetes in Lower Eastern Province, Kenya. J. Ethnopharmacol. 2012, 139, 74-80. [CrossRef] [PubMed]

26. Raj, V. Plant Opuntia Dillenii: A Review on Its Traditional Uses, Phytochemical and Pharmacological Properties. EC Pharm. Sci. 2015, 1, 29-43. 
27. Zhao, X.; Yang, J.; Tong, Z.; Zhou, Y.; Zhang, W.; Qi, S.; Yuan, G. Clinical Observation of Opuntia Dillenii Tablet in Treating Type 2 Diabetes Mellitus. Chin. J. Integr. Tradit. West. Med. 2002, 8, 215-218.

28. Qiu, Y.K.; Zhao, Y.Y.; Dou, D.Q.; Xu, B.X.; Liu, K. Two new $\alpha$-pyrones and other components from the cladodes of Opuntia dillenii. Arch. Pharmacal Res. 2007, 30, 665-669. [CrossRef]

29. De Paz, P.L.P.; Medina, I.M. Catalogo de Las Plantas Medicinales de La Flora Canaria: Applicaciones Populares; Instituto de Estudios canaries: Tenerife, Spain, 1988; ISBN 84-404-1458-7. (In Spanish)

30. Khan, M.P.Z.; Ahmad, M.; Zafar, M.; Sultana, S.; Ali, M.I.; Sun, H. Ethnomedicinal uses of Edible Wild Fruits (EWFs) in Swat Valley, Northern Pakistan. J. Ethnopharmacol. 2015, 173, 191-203. [CrossRef] [PubMed]

31. Perfumi, M.; Tacconi, R. Antihyperglycemic Effect of Fresh Opuntia dillenii Fruit from Tenerife (Canary Islands). Int. J. Pharmacogn. 1996, 34, 41-47. [CrossRef]

32. Berraaouan, A.; Abderrahim, Z.; Hassane, M.; AbdelKhaleq, L.; Mohammed, A.; Mohamed, B. Evaluation of protective effect of cactus pear seed oil (Opuntia ficus-indica L. MILL.) against alloxan-induced diabetes in mice. Asian Pac. J. Trop. Med. 2015, 8, 532-537. [CrossRef]

33. Loukili, E.H.; Abrigach, F.; Bouhrim, M.; Bnouham, M.; Fauconnier, M.-L.; Ramdani, M. Chemical Composition and Physicochemical Analysis of Opuntia dillenii Extracts Grown in Morocco. J. Chem. 2021, 2021, 1-11. [CrossRef]

34. Berraaouan, A.; Ziyyat, A.; Mekhfi, H.; Legssyer, A.; Sindic, M.; Aziz, M.; Bnouham, M. Evaluation of antidiabetic properties of cactus pear seed oil in rats. Pharm. Biol. 2014, 52, 1286-1290. [CrossRef]

35. Haidara, M.A.; Ibrahim, I.M.; Al-Tuwaijri, A.S.; Awadalla, S.A.; Yaseen, H. Effect of $\alpha$-Tocopherol on Glucose Uptake and Contractility in Rat Skeletal Muscle. Med Sci. Monit. 2003, 9, BR174-BR177.

36. Ghazi, Z.; Ramdani, M.; Tahri, M.; Rmili, R.; Elmsellem, H.; Mahi, B.E.; Fauconnier, M.L. Chemical Composition and Antioxidant Activity of Seeds Oils and Fruit Juice of Opuntia Ficus Indica and Opuntia Dillenii from Morocco. J. Mater. Environ. Sci 2015, 6, 2338-2345.

37. Bnouham, M.; Bouhrim, M.; Ouassou, H.; Choukri, M.; Mekhfi, H.; Ziyyat, A.; Legssyer, A.; Aziz, M. Hepatoprotective effect of Opuntia dillenii seed oil on CCl4 induced acute liver damage in rat. Asian Pac. J. Trop. Biomed. 2018, 8, 254. [CrossRef]

38. Bnouham, M.; Bouhrim, M.; Ouassou, H.; Loukili, E.H.; Ramdani, M.; Mekhfi, H.; Ziyyat, A.; Legssyer, A.; Aziz, M. Antidiabetic effect of Opuntia dillenii seed oil on streptozotocin-induced diabetic rats. Asian Pac. J. Trop. Biomed. 2019, 9, 381-388. [CrossRef]

39. Bouhrim, M.; Daoudi, N.E.; Ouassou, H.; Benoutman, A.; Loukili, E.H.; Ziyyat, A.; Mekhfi, H.; Legssyer, A.; Aziz, M.; Bnouham, M.; et al. Phenolic Content and Antioxidant, Antihyperlipidemic, and Antidiabetogenic Effects of Opuntia dillenii Seed Oil. Sci. World J. 2020, 2020, 1-8. [CrossRef]

40. Aragno, M.; Mastrocola, R.; Catalano, M.G.; Brignardello, E.; Danni, O.; Boccuzzi, G. Oxidative Stress Impairs Skeletal Muscle Repair in Diabetic Rats. Diabetes 2004, 53, 1082-1088. [CrossRef]

41. Yadav, P.; Sarkar, S.; Bhatnagar, D. Action of capparis deciduaagainst alloxan-induced oxidative stress and diabetes in rat tissues. Pharmacol. Res. 1997, 36, 221-228. [CrossRef]

42. Guillet, C. Implication Des Produits Terminaux de Glycation Dans Les Complications Liées Au Diabète. Nutr. Clin. Métabolisme 2010, 24, 109-114. (In French) [CrossRef]

43. D'Amico, M.; Marfella, R.; Nappo, F.; DiFilippo, C.; De Angelis, L.; Berrino, L.; Rossi, F.; Giugliano, D. High Glucose Induces Ventricular Instability and Increases Vasomotor Tone in Rats. Diabetologia 2001, 44, 464-470. [CrossRef] [PubMed]

44. Tomimatsu, T.; Horie, T. Enhanced Glucose Absorption in the Rat Small Intestine Following Repeated Doses of 5-Fluorouracil. Chemico-Biol. Interact. 2005, 155, 129-139. [CrossRef] [PubMed]

45. Shai, L.J.; Masoko, P.; Mokgotho, M.P.; Magano, S.R.; Mogale, A.M.; Boaduo, N.; Eloff, J.N. Yeast Alpha Glucosidase Inhibitory and Antioxidant Activities of Six Medicinal Plants Collected in Phalaborwa, South Africa. S. Afr. J. Bot. 2010, 76, 465-470. [CrossRef]

46. Loizzo, M.R.; Saab, A.M.; Tundis, R.; Menichini, F.; Bonesi, M.; Piccolo, V.; Statti, G.A.; de Cindio, B.; Houghton, P.J.; Menichini, F. In Vitro Inhibitory Activities of Plants Used in Lebanon Traditional Medicine against Angiotensin Converting Enzyme (ACE) and Digestive Enzymes Related to Diabetes. J. Ethnopharmacol. 2008, 119, 109-116. [CrossRef]

47. Clemens, K.K.; McArthur, E.; Dixon, S.N.; Fleet, J.L.; Hramiak, I.; Garg, A.X. The Hypoglycemic Risk of Glyburide (Glibenclamide) Compared with Modified-Release Gliclazide. Can. J. Diabetes 2015, 39, 308-316. [CrossRef] [PubMed]

48. Koubaa, M.; Mhemdi, H.; Barba, F.J.; Angelotti, A.; Bouaziz, F.; Chaabouni, S.E.; Vorobiev, E. Seed Oil Extraction from Red Prickly Pear Using Hexane and Supercritical $\mathrm{CO}_{2}$ : Assessment of Phenolic Compound Composition, Antioxidant and Antibacterial Activities. J. Sci. Food Agric. 2016, 97, 613-620. [CrossRef] [PubMed]

49. Ghazi, Z.; Ramdani, M.; Fauconnier, M.L.; Mahi, B.E.; Cheikh, R. Fatty Acids Sterols and Vitamin E Composition of Seed Oil of Opuntia ficus Indica and Opuntia dillenii from Morocco. J. Mater. Environ. Sci. 2013, 4, 967-972.

50. Mobraten, K.; Haug, T.M.; Kleiveland, C.R.; Lea, T. Omega-3 and Omega-6 PUFAs Induce the Same GPR120-Mediated Signalling Events, but with Different Kinetics and Intensity in Caco-2 Cells. Lipids Health Dis. 2013, 12, 101. [CrossRef] [PubMed]

51. Holaly, G.E.; Efui Holaly, G.; Kodjovi, A.; Simplice Damintoti, K.; Kokou, A.; Yao, A.; Gérard, T.; Blaise, A.; Jacques, S.; Messanvi, G. Composés Bioactifs Isolés Des Plantes à Propriété Anti-Diabétique: Revue de Littérature [Isolated Bioactive Plant Compounds with Anti-Diabetic Property: Review]. Int. J. Innov. Appl. Stud. 2017, 19, 839-849.

52. Ganapaty, S.; Nandeesh, R.; Veerapur, V.P.; Thippeswamy, B.; Shivasharan, D. In vivo and In vitro Anti-Diabetic Effects of Madhuca indica Roxb. Alloxan-Induc. Diabet. Rats IJAPBC 2013, 2, 282-290. 
53. Kumar, S.; Kumar, V.; Prakash, O. Enzymes Inhibition and Antidiabetic Effect of Isolated Constituents from dillenia indica. BioMed Res. Int. 2013, 2013, 1-7. [CrossRef]

54. Somani, R.; Kasture, S.; Singhai, A.K. Antidiabetic Potential of Butea Monosperma in Rats. Fitoterapia 2006, 77, 86-90. [CrossRef] [PubMed]

55. Panda, S.; Jafri, M.; Kar, A.; Meheta, B.K. Thyroid Inhibitory, Antiperoxidative and Hypoglycemic Effects of Stigmasterol Isolated from Butea Monosperma. Fitoterapia 2009, 80, 123-126. [CrossRef]

56. Båvenholm, P.N.; Pigon, J.; Östenson, C.G.; Efendic, S. Insulin Sensitivity of Suppression of Endogenous Glucose Production Is the Single Most Important Determinant of Glucose Tolerance. Diabetes 2001, 50, 1449-1454. [CrossRef]

57. Zhang, Y.; Oguzhan, B.; Louchami, K.; Chardigny, J.-M.; Portois, L.; Carpentier, Y.A.; Malaisse, W.J.; Herchuelz, A.; Sener, A. Pancreatic islet function in $\omega-3$ fatty acid-depleted rats: Alteration of calcium fluxes and calcium-dependent insulin release. Am. J. Physiol. Metab. 2006, 291, E441-E448. [CrossRef]

58. Manco, M.; Calvani, M.; Mingrone, G. Effects of dietary fatty acids on insulin sensitivity and secretion. Diabetes Obes. Metab. 2004, 6, 402-413. [CrossRef]

59. Nugent, C.; Prins, J.B.; Whitehead, J.P.; Wentworth, J.M.; Chatterjee, V.K.K.; O’Rahilly, S. Arachidonic Acid Stimulates Glucose Uptake in 3T3-L1 Adipocytes by Increasing GLUT1 and GLUT4 Levels at the Plasma Membrane. J. Biol. Chem. 2001, 276, 9149-9157. [CrossRef] [PubMed]

60. Sampaio, E.M.; Furtado, F.A.S.; Furtado, J.S.; Cavalacante, M.N.N.; Riedel, O.O. Hypoglycemia-Producing Activities of Raw Coffee Beans (Coffea arabica). Rev. Med. Univ. Fed. Ceara 1979, 19, 49-54.

61. Sattar, N.A.; Hussain, F.; Iqbal, T.; Sheikh, M.A. Determination of in vitro antidiabetic effects of Zingiber officinale Roscoe. Braz. J. Pharm. Sci. 2012, 48, 601-607. [CrossRef]

62. Nammi, S.; Sreemantula, S.; Roufogalis, B.D. Protective Effects of Ethanolic Extract of Zingiber officinale Rhizome on the Development of Metabolic Syndrome in High-fat Diet-fed Rats. Basic Clin. Pharmacol. Toxicol. 2009, 104, 366-373. [CrossRef] [PubMed]

63. Bansal, P.; Paul, P.; Mudgal, J.; Nayak, P.G.; Thomas Pannakal, S.; Priyadarsini, K.I.; Unnikrishnan, M.K. Antidiabetic, Antihyperlipidemic and Antioxidant Effects of the Flavonoid Rich Fraction of Pilea microphylla (L.) in High Fat Diet/Streptozotocin-Induced Diabetes in Mice. Exp. Toxicol. Pathol. 2012, 64, 651-658. [CrossRef]

64. Abdelmoaty, M.A.; Ibrahim, M.A.; Ahmed, N.S.; Abdelaziz, M.A. Confirmatory Studies on the Antioxidant and Antidiabetic Effect of Quercetin in Rats. Indian J. Clin. Biochem. 2010, 25, 188-192. [CrossRef] [PubMed]

65. Moorthi, R.V.; Bobby, Z.; Selvaraj, N.; Sridhar, M.G. Vitamin E Protects the Insulin Sensitivity and Redox Balance in Rat L6 Muscle Cells Exposed to Oxidative Stress. Clin. Chim. Acta 2006, 367, 132-136. [CrossRef]

66. Labuschagne, M.T.; Hugo, A. Oil Content and Fatty Acid Composition of Cactus Pear Seed Compared with Cotton and Grape Seed. J. Food Biochem. 2010, 34, 93-100. [CrossRef]

67. Chang, S.F.; Hsieh, C.L.; Yen, G.C. The Protective Effect of Opuntia dillenii Haw Fruit against Low-Density Lipoprotein Peroxidation and Its Active Compounds. Food Chem. 2008, 106, 569-575. [CrossRef]

68. Salvo, F.; Galati, E.M.; Curto, S.L.; Tripodo, M.M. Study on the Chemical Characterization of Lipid Composition of Opuntia Ficus indica L. Seed Oil. Riv. Ital. Delle Sostanze Grasse 2002, 79, 395-398.

69. El Mannoubi, I.; Barrek, S.; Skanji, T.; Casabianca, H.; Zarrouk, H. Characterization of Opuntia Ficus indica Seed Oil from Tunisia. Chem. Nat. Compd. 2009, 45, 616-620. [CrossRef]

70. Matthäus, B.; Özcan, M.M. Habitat Effects on Yield, Fatty Acid Composition and Tocopherol Contents of Prickly Pear (Opuntia Ficus indica L.) Seed Oils. Sci. Hortic. 2011, 131, 95-98. [CrossRef]

71. National Research Council. Guide for the Care and Use of Laboratory Animals, 8th ed.; The National Academies Press: Washington, DC, USA, 2011; ISBN 9780309154000.

72. Bellahcen, S.; Mekhfi, H.; Ziyyat, A.; Legssyer, A.; Hakkou, A.; Aziz, M.; Bnouham, M. Prevention of Chemically Induced Diabetes Mellitus in Experimental Animals by Virgin Argan Oil. Phytotherapy Res. 2012, 26, 180-185. [CrossRef] [PubMed]

73. Luzi, L.; Pozza, G. Glibenclamide: An Old Drug with a Novel Mechanism of Action? Acta Diabetol. 1997, 34, 239-244. [CrossRef] [PubMed]

74. Nishigaki, A.; Noma, H.; Kakizawa, T. The relations between doses of streptozotocin and pathosis in induced diabetes mellitus. Shika gakuho. Dent. Sci. Rep. 1989, 89, 639-662.

75. Rossetti, L.; Smith, D.; Shulman, G.; Papachristou, D.; DeFronzo, R. Correction of Hyperglycemia with Phlorizin Normalizes Tissue Sensitivity to Insulin in Diabetic Rats. J. Clin. Investig. 1987, 79, 1510-1515. [CrossRef]

76. Bnouham, M.; Merhfour, F.Z.; Ziyyat, A.; Mekhfi, H.; Aziz, M.; Legssyer, A. Antihyperglycemic Activity of the Aqueous Extract of Urtica dioica. Fitoterapia 2003, 74, 677-681. [CrossRef]

77. Eto, B.; Boisset, M.; Griesmar, B.; Desjeux, J.F. Effect of Sorbin on Electrolyte Transport in Rat and Human Intestine. Am. J. Physiol. Liver Physiol. 1999, 276, G107-G114. [CrossRef] [PubMed]

78. Daoudi, N.E.; Bouhrim, M.; Ouassou, H.; Legssyer, A.; Mekhfi, H.; Ziyyat, A.; Aziz, M.; Bnouham, M. Inhibitory Effect of Roasted/ Unroasted Argania spinosa Seeds Oil on $\alpha$-Glucosidase, $\alpha$-Amylase and Intestinal Glucose Absorption Activities. S. Afr. J. Bot. 2020, 135, 413-420. [CrossRef] 
79. Mechchate, H.; Es-safi, I.; Louba, A.; Alqahtani, A.S.; Nasr, F.A.; Noman, O.M.; Farooq, M.; Alharbi, M.S.; Alqahtani, A.; Bari, A.; et al. In Vitro Alpha-Amylase and Alpha-Glucosidase Inhibitory Activity and In Vivo Antidiabetic Activity of Withania frutescens L. Foliar Extract. Molecules 2021, 26, 293. [CrossRef]

80. Ouassou, H.; Zahidi, T.; Bouknana, S.; Bouhrim, M.; Mekhfi, H.; Ziyyat, A.; Legssyer, A.; Aziz, M.; Bnouham, M. Inhibition of $\alpha$ -Glucosidase, Intestinal Glucose Absorption, and Antidiabetic Properties by Caralluma europaea. Evid. Based Complement. Altern. Med. 2018, 2018, 1-8. [CrossRef] [PubMed]

81. Gholamhoseinian, A.; Fallah, H. Inhibitory Effect of Methanol Extract of Rosa damascena Mill. Flowers on $\alpha$-Glucosidase Activity and Postprandial Hyperglycemia in Normal and Diabetic Rats. Phytomedicine 2009, 16, 935-941. [CrossRef] [PubMed] 